Article

\title{
Understanding the Stakeholders' Involvement in Utilizing Municipal Solid Waste in Agriculture through Composting: A Case Study of Hanoi, Vietnam
}

\author{
Nam Phong Le ${ }^{1,2, *}$, Thi Thu Phuong Nguyen ${ }^{3,4}$ and Dajian Zhu ${ }^{3}$ (D) \\ 1 College of Architecture and Urban Planning, Tongji University, Siping Road 1239, Shanghai 200092, China \\ 2 Faculty of Architecture and Planning, National University of Civil Engineering, 55 Giai phong, \\ Hanoi 100000, Vietnam \\ 3 Department of Public Administration, School of Economics and Management, Tongji University, \\ Tongji Building A, Siping Road 1500, Shanghai 200092, China; nguyenthuphuong1979@gmail.com (T.T.P.N.); \\ dajianzhu@263.net (D.Z.) \\ 4 Faculty of Economics and Rural Development, Vietnam National University of Agriculture, Trau Quy, \\ Gia Lam, Hanoi 100000, Vietnam \\ * Correspondence: lenamphong.vn@gmail.com; Tel.: +848-6866-5488
}

Received: 7 June 2018; Accepted: 2 July 2018; Published: 4 July 2018

\begin{abstract}
Although the involvement of stakeholders is believed to be the key to the success of sustainable municipal waste management, the specific features of stakeholders, as well as their interdependence, have been under-researched. This study employed a multilevel governance approach to understand the manner in which different types of stakeholder networks interact with one another and how their roles should be reinforced. A combination of stakeholder analysis (SA) and social network analysis (SNA) was employed to investigate the perspective of stakeholders in utilizing municipal solid waste (MSW) in agriculture in Hanoi, Vietnam. SA indicated that the local authorities take the main responsibility for the management of MSW in Hanoi. Although other stakeholders express a significant interest in recycling MSW through composting, many of them do not have sufficient power to make any changes to the current system. SNA revealed the fragmentation of the network, as the coordination among the stakeholders is dominated by hierarchical governance, while there is a lack of horizontal cooperation among the sectors. The fragmentation could be attributed to weak legislative framework, lack of trust, financial constraints, and the limited participation of private enterprises. The governance of MSW use in agriculture should be executed through interdependency rather than hierarchy and through a network comprising both state and non-state actors.
\end{abstract}

Keywords: municipal solid waste; organic waste; stakeholders; composting; social network analysis; agriculture

\section{Introduction}

As in other cities in Asian developing countries, organic waste in Hanoi accounts for the largest proportion of the municipal solid waste (MSW). The city produces more than 6500 tonnes of solid waste per day, and the average amount of MSW generated daily per capita is $0.9 \mathrm{~kg}$. It is estimated that by 2020, this figure will have reached $1.4 \mathrm{~kg} /$ day [1]. Its weight is increasing rapidly along with the increase in population and the rapid urbanization process of a city that has been geographically and administratively expanded [2]. Apart from bad odors and unsightliness, organic waste has also caused serious environmental degradation and negative impacts on public health [3,4]. 
Utilizing urban waste in agriculture production through composting has been considered as a suitable option to cope with urban waste issues in developing countries [3-9]. This alternative may be attributed to economic, environmental, and social factors, such as the costs associated with landfilling and the transportation of waste, the pollution impacts of accumulated solid waste, public health threats, and Not In My Back Yard (NIMBY) conflicts. It further helps to improve the fertility of the soil because of the large amount of organic matter contained in waste streams in these countries $[10,11]$. Aware of not only the threats from pollution, but also the opportunities for recycling organic waste, the government of Vietnam approved the National Strategy for Integrated Management of Solid Wastes until 2025 and Vision Towards 2050. It stresses that organic waste needs to be managed in a cycle, involving the separation of the waste, composting, and utilization of the compost in the arable land of the city.

However, the question is how to translate the national strategy into the local context when a number of composting projects initiated over the past decades have failed in most developing countries [12,13]. As is the case in many other environmental situations, utilizing MSW through composting requires a holistic approach involving a range of different stakeholders. This suggests that any decision meant to improve the effectiveness of SWM must seriously consider the perceptions, interests, and roles of all the parties involved [14]. In other words, the success in solid waste management depends on the extent to which stakeholders are integrated into the management process, thus harnessing their respective resources to build collective strength with a clear division of roles and responsibilities [15]. So far, with a top-down approach, the municipal authorities of most developing countries retain a key role in the largest part of the solid waste management process [16]. The lack of the involvement of private enterprises, end-users of recycled products, local communities, and other relevant stakeholders in the waste management process is the main reason for the crisis regarding solid waste management $[4,13,16]$. The literature reveals that the problem of implementing sustainable municipal solid waste management lies in its practical application $[17,18]$. The practical issues of ability, agreement, coordination, collaboration, and obligations were discussed in the literature $[5,15,16]$. These problems have been associated with ineffective government policy, poor administration, failures to involve the private sector and local communities, and lack of effective communication $[16,19,20]$. As a result, low levels of awareness, problems with coordination and bureaucracy, the delicacy of common interests, institutional fragmentation, failure to clarify goals, and an unwillingness to make significant changes to current behavior have existed among stakeholders [13,21,22].

Where the formal problem-solving structures of government are ill-fitted to solve complex problems [23], it may be necessary to use governance networks to integrate the required distributed capacities into a problem-solving framework that is more reflexive and thus more conducive to the achievement of development goals [24]. The adoption of multilevel governance framework has proven to be useful to that end $[25,26]$. The main value of multilevel governance framework is that it allows for an understanding of complexity at and between levels. The vertical dimension refers to the linkages between higher and lower levels of government, while horizontal dimension focuses on the cooperation arrangement between state, market, and civil society actors. These two dimensions often coexist and link to each other [25]. The use of the governance network approach has been extensively employed to develop conceptual frameworks for addressing the field of environmental management. For example, Francesch-Huidobro [26], based on a multilevel governance perspective, set out a conceptual framework to examine the governing mechanisms through climate change mitigation and energy decisions that are made in Shanghai, China. Likewise, some have applied a social network approach to analyze natural resources governance [27], as well as MSW management [14,28]. Indeed, the development of governance networks can significantly address the common dilemmas in MSW management. For example, Taiwan has been seen as having a successful practice for targeting urban solid waste, thanks to the engagement of various stakeholders in the MSW management [29].

According to Ravetz [30], for cities to be sustainable, there is a need to move towards a situation where the through-put of resources is reduced (i.e., where it contains its own eco-cycle. This is also 
the basic philosophy of the circular economy, which has received increasing attention worldwide as a way to increase the efficiency of resource-use-based adoption of closing-the-loop production patterns within an economic system [31]. Returning organic matter from urban waste back to agriculture soil is one part of this process (Figure 1). The challenge of linking urban waste to agriculture is that waste must be separated at the source. Waste separation provides a steady supply of organic waste for composting plants. For municipal solid waste, which is high in volume, diverse in nature, and complicated in composition, the most economical and sustainable measure for waste separation is one that relies on residents who directly generate it. Once the separated waste has been composted, the end-product-compost—is believed to provide a productive resource to agriculture. While most composting projects are successful in producing compost, the sustainability of a commercial composting plant will depend on the sale of compost products. The use of compost in agriculture, therefore, ultimately depends on the acceptance of the end-users (i.e., farmers (Figure 1)). Linking urban waste to urban agriculture, then, presents a systemic problem, which involves a wide range of stakeholders: local residents, waste collectors, waste management officials, composting plants, agriculture development agencies, compost users (farmers), and so forth.

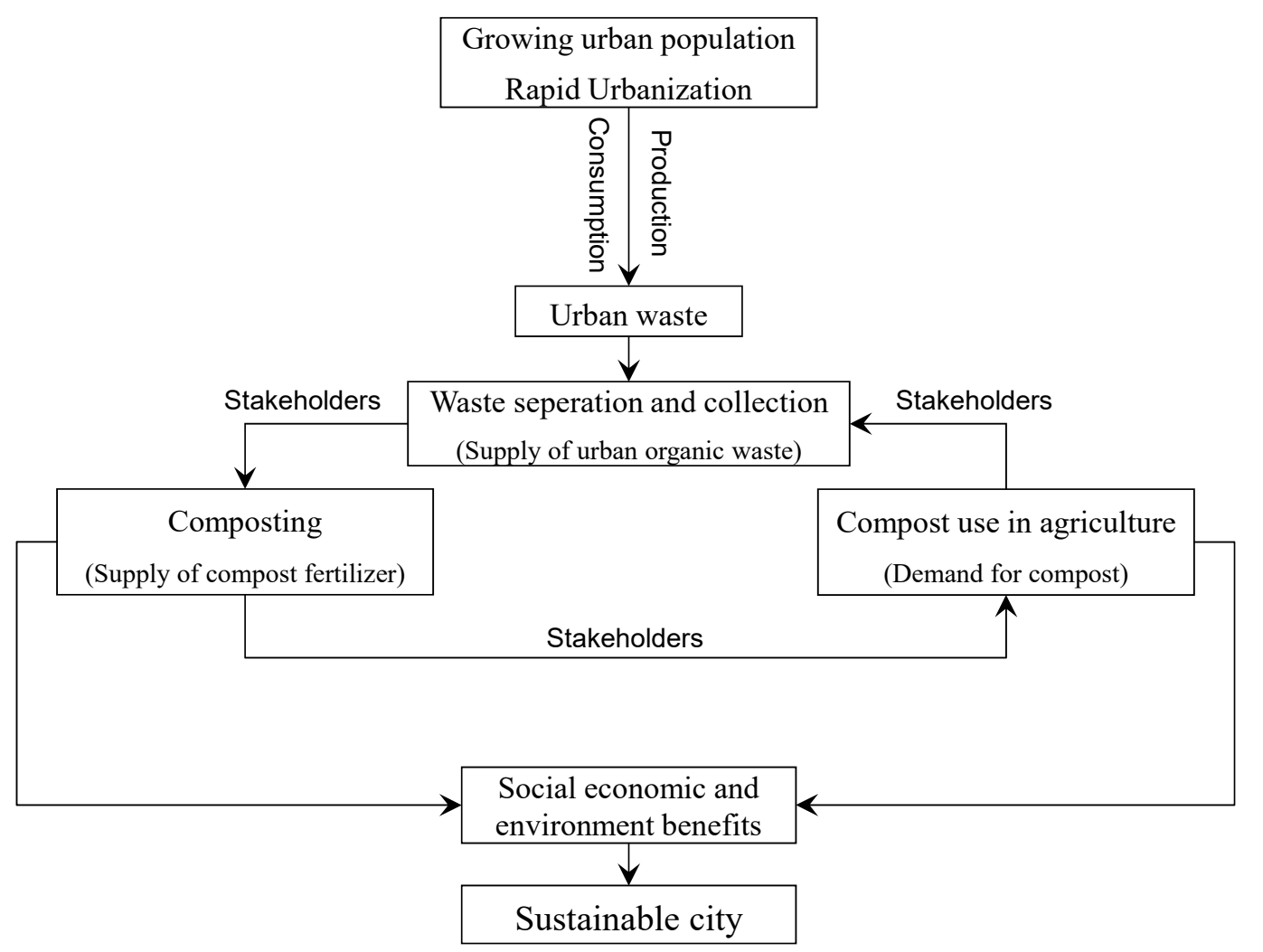

Figure 1. The conceptual illustration of the research idea.

Based on integrated sustainable waste management [15], this study considers utilizing urban waste in agriculture in a system that consists of the three main components, including (i) system elements-stages in the organic waste management process: waste separation and collection; composting and compost use in agriculture; (ii) aspects-technical, economic, social, institutional, and legal; and (iii) stakeholders-participants in MSW management process. These stakeholders, in many ways, influence various system elements (waste generation and separation, composting, use of compost) through environmental, financial, institutional, legal, and social aspects. Bringing different stakeholders together in the decision-making process is vital. However, very little attention has been given to the stakeholders' characteristics, their relationships, and how they influence one another. 
Only by understanding the nature of their interest and inter-relationships can these stakeholders be effectively involved in the system.

To assess the participation of stakeholders in the management of resources and environmental and public administration, stakeholder analysis (SA) is widely used and has proven to be an effective method $[27,32,33]$. The set of tools included in SA helps to collect qualitative data and generates a general understanding of "a system, and for assessing the impacts of changes to that system, by means of identifying the key stakeholders and assessing their respective interests" [34] (p. 1). Furthermore, "the purpose of stakeholder analysis is to indicate whose interests should be taken into account when making a decision" [35] (p. 1). While it was used originally in management science to address the interests of business stakeholders, this method has now become increasingly popular in analyzing the complex situations in environment and resource management, because it helps us to understand the systems and thus propose necessary changes [36]. In the field of waste management, this method has been employed in various studies to assess the level of knowledge, awareness, interest, and the roles of relevant stakeholders. For example, Snel and Ali [37] applied SA to examine stakeholder participation in local waste management systems in Pakistan and India. In Vietnam, SA has been employed to identify the constraints to the success of rural sanitation promotion campaigns [38]. Zurbrugg [39] utilized SA to indicate that the cooperatives and microenterprises engaged in primary waste collection are considered an important element of the waste management process in Managua.

While SA seems to be a strong qualitative tool that helps to understand the interests and characteristics of stakeholders, it has limitations in assessing the relations and interactions among them. Social network analysis (SNA) offers a solution to this, because it allows for a systematic analysis of relationships, which, according to Wasserman and Faust [40], are important among these multilevel players. By definition, SNA is "a research technique that focuses on identifying and comparing the relationships within and between individuals, groups, and systems in order to model the real world interactions at the heart of organizational knowledge and learning processes" [41] (p. 25). SNA has been developed, on the basis of a set of well-proven methods and theories, to contribute to the formulation of quantitative measures of many qualitative concepts that have long been used in the study of society, such as fragmentation, reciprocity, interaction, hierarchy, and cooperation [40,42]. This method has recently been extensively applied in studies about natural resource management and public governance issues [43-45]. For instance, Stein et al. [46] used SNA to map out the social complexity that underpins water resource governance in the Mkindo catchment, Tanzania. Cohen et al. [47] examined a governance network involved in adaptive co-management of coastal ecosystems in the Solomon Islands to indicate that that geographic, logistical, and institutional barriers to cross-scale coordination and learning might hamper coordination and learning among management actors. Hauck et al. [48] applied social network analysis to understand the stakeholders' engagement in agriculture biodiversity governance at the local and regional level.

In the last few years, an important methodological trend has developed rapidly to integrate qualitative and quantitative research methods, that is, to employ a "mixed methods" approach $[49,50]$. In line with this trend, several studies have combined SA and SNA to investigate not only stakeholders' characteristics but also their interactions that help to enhance the co-management processes in environmental and resources management [44,51]. For instance, Lienert et al. [27] demonstrated the added value of combining SA and SNA in examining infrastructure planning in the Swiss water sector. In the field of waste management, this methodological approach has recently been applied by various researchers. For example, Caniato et al. [14] indicated that the integration of SA and SNA allows for better understanding of actors' roles and actions, analyzing driving forces and existing coordination among stakeholders in the On-Nuch infectious waste incinerator in Bangkok, Thailand. $\mathrm{Xu}$ et al. [33] used this approach to investigate how the mechanism of food waste management functioned in Beijing, China.

In Vietnam, the specific features of each of relevant stakeholder, as well as their interdependence in their respective local settings, have been under-researched. This study remedies this by employing 
the multilevel governance framework to explain the governing mechanism through which different types of stakeholders interact with one another and strengthen their roles. More specifically, this study investigates the perspectives of stakeholders in utilizing municipal organic waste in urban agriculture by (i) examining what roles stakeholders could play in relation to the system; (ii) investigating how their knowledge, attitude, interest, power, and alliances can influence the system; and (iii) understanding how stakeholders representing different levels and sectors are integrated into the co-management processes of utilizing urban organic waste in agriculture. A combination of stakeholder analysis and social network analysis was employed to assess these aspects. This methodological approach allows for the analysis of both the characteristics of the stakeholders and their interrelations in the system. Based on the results of the baseline study on the features and relations between different parties, the study creates the potential for strengthening the critical ties among the different parties in the system. Opportunities for and obstacles against turning organic waste from a burden in the management of an urban environment into a resource for agricultural production vary from one country or region to another. One system may function well in this case and yet still fail in another. This study is conducted to present solutions for one particular locality in a specific set of situations. However, it is the authors' hope that the general approach and methodology of this study can be replicated in similar cities of other developing countries.

\section{Methodology}

\subsection{Study Site}

As in most other cities in developing countries, municipal solid waste management has been a big challenge for Hanoi-the capital and the largest city of Vietnam. Following an administrative expansion in August 2008, Hanoi now has a total area of $3328.89 \mathrm{~km}^{2}$ and consists of 10 urban districts, 17 suburban districts, and one town (Figure 2) [52]. In recent decades, the combined effects of changes in lifestyle, burgeoning population, and rapid urbanization have led to a rise in the volume of municipal solid waste.

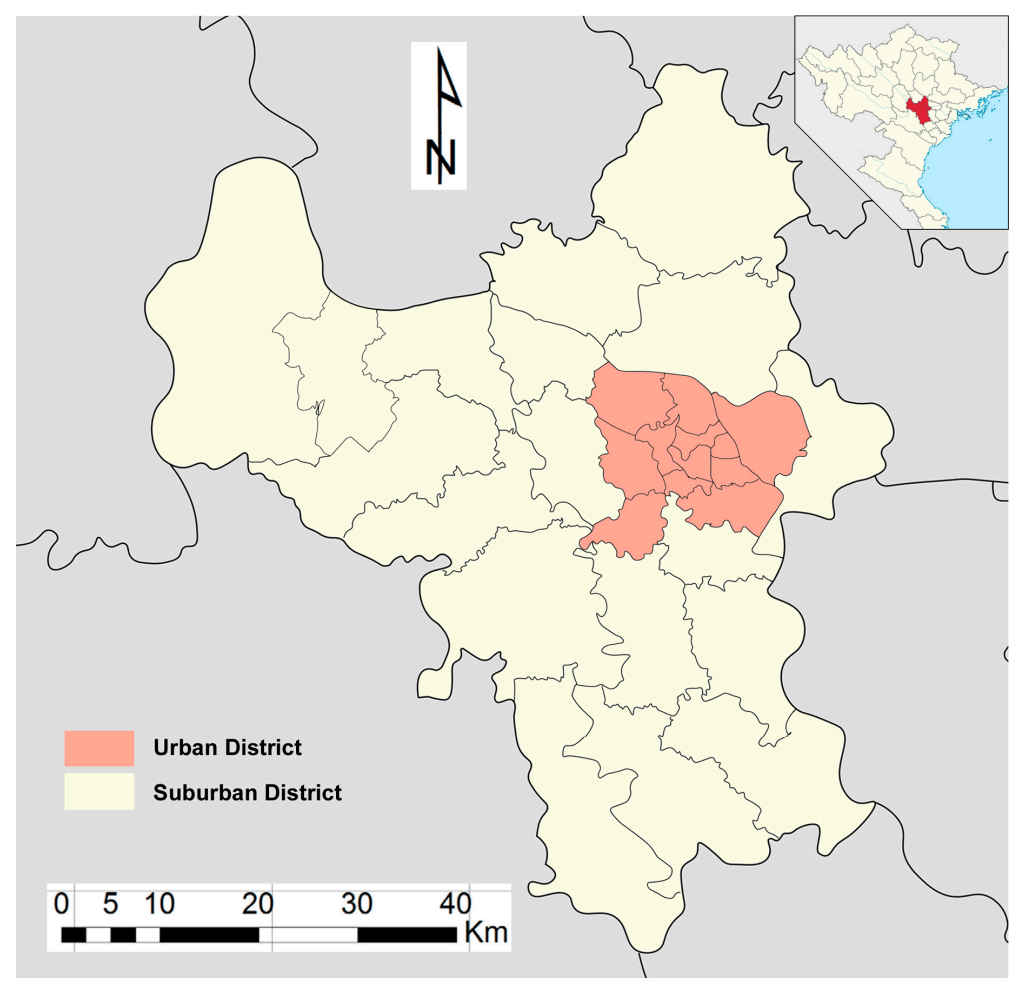

Figure 2. Location of the study site. 
According to Hanoi People's Committee (HPC) [2], MSW generation in Hanoi was about 5371 tonnes per day in 2010. The central urban areas account for 3200 tonnes of this volume. The remaining 2171 tonnes were produced in rural areas. This figure is expected to grow rapidly over the next decades, estimated at 8440 tonnes in 2020 and 11,305 tonnes in 2030 (Table 1).

Table 1. Current and estimated volumes of municipal solid waste (MSW) in Hanoi.

\begin{tabular}{ccccc}
\hline Area & $\mathbf{2 0 1 0}$ & $\mathbf{2 0 2 0}$ & $\mathbf{2 0 3 0}$ & $\mathbf{2 0 5 0}$ \\
\hline Total volume of MSW generated per day (tonnes/day) & 5371 & 8440 & 11,305 & 15,855 \\
Urban area & 3200 & 6374 & 9161 & 12,809 \\
Peri-urban and rural areas & 2171 & 2066 & 2144 & 3046 \\
\hline
\end{tabular}

(Source: Hanoi People Committee [2]).

Waste in Hanoi, most of which is organic waste $(60 \%)$ with low caloric values, is characterized by a significantly higher density and moisture (Table 2). While the waste treatment process relies mainly on landfill sites, these sites are nearing their limits and thus need to be expanded and have their capacity enhanced. Meanwhile, the city is confronted with a shortage of available land for constructing landfills. This is the most urgent and contested issue, given the rise of the NIMBY movement, in which the local people protested the construction of waste burial grounds immediately adjacent to their houses.

Table 2. The composition of municipal solid waste in Hanoi.

\begin{tabular}{cc}
\hline Composition & Rate (\%) \\
\hline Organic matter & 60.00 \\
Paper & 5.40 \\
Plastic & 11.00 \\
Metal & 0.87 \\
Glass & 1.64 \\
Leather, rubber, and timber & 2.66 \\
Textile fabric & 5.82 \\
Rock and soil, ash, sand, etc. & 12.61 \\
Total & 100.00 \\
\hline
\end{tabular}

Source: National Annual Report on Environment [1].

Given the current waste situations and the socio-economic conditions of Hanoi, composting has been regarded as the most appropriate method of treatment, so far, for MSW generated in the city. However, only $2.5-7 \%$ of the total generated waste is currently recycled by composting [53]. In addition, the consumption of compost, similar to other countries in the region, is not as high as expected for various reasons, including quality, price, market expansion, and institutional issues [6]. Although the solid waste taken to the factories to be turned into compost has an organic density of between $60 \%$ and $65 \%$, the amount of post-treatment discharged solid waste that must be buried by the factories themselves is about $35-40 \%$ of the input waste. This is because this solid waste was not separated at the source [1]. The failure to separate waste at the source leads to a higher operation cost and low-quality compost, making them unappealing and hardly marketable. Finding a market for compost has been a critical issue when the compost is discharged rather than applied to agricultural land.

Meanwhile, agricultural production is intimately linked to the overall economic development of the city, because more than $50 \%$ of the population of Hanoi lives in the rural area and relies on agriculture as the main livelihood. However, the contribution of agriculture to GDP is decreasing and is much lower than that of other industries and the service sector (Figure 3). 


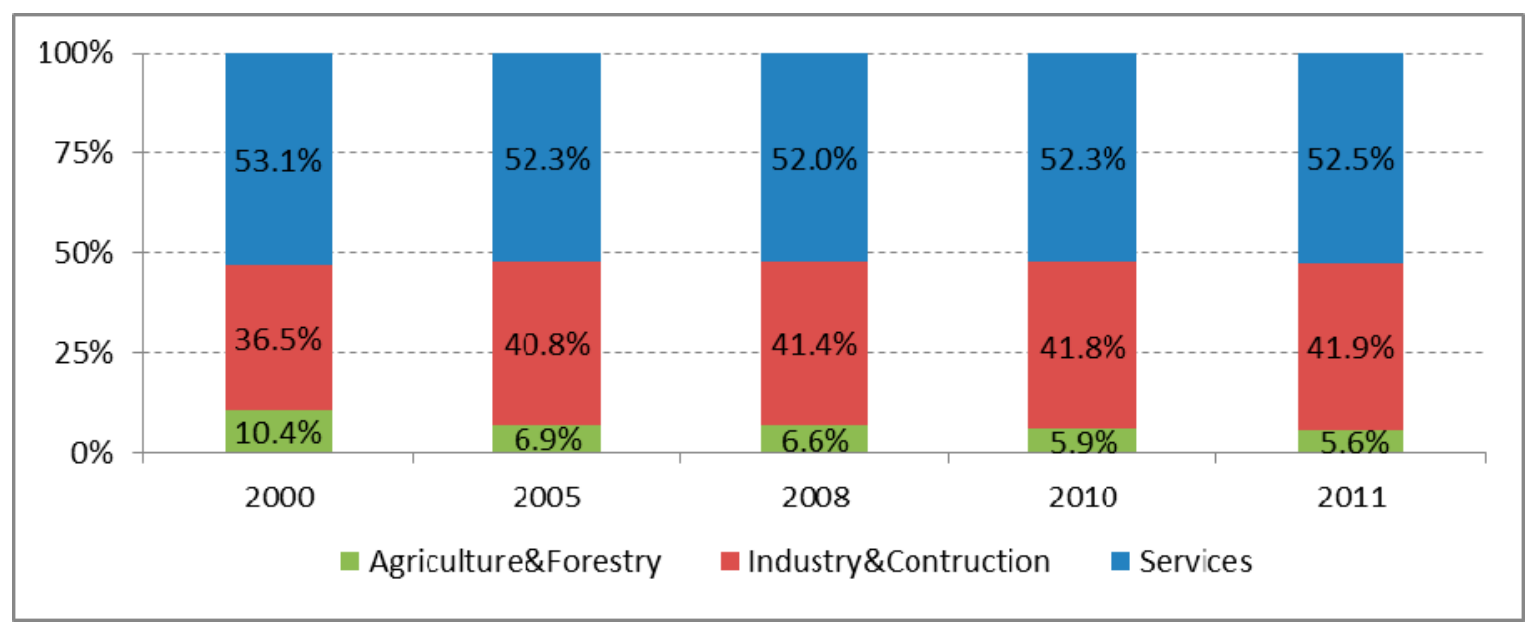

Figure 3. The economic structure of Hanoi between 2000 and 2011 (\%). (Source: Hanoi statistical Office [52]).

In agriculture, cultivation is labor-intensive and thus attracts a fair number of workers. In recent years, there has been a rapid shift from the production of food to the cultivation of green vegetables and orchards, which is becoming more and more lucrative. The planting of flowers and decorative plants is also expanding, generating high income for urban farmers. However, excessive use of artificial fertilizers and pesticides is causing negative impacts on the environment and human health, as well as consumers and producers alike. Unless properly processed, self-made organic fertilizers, such as chicken dung, manure, and incubated soybeans, will not only stink but also cause environmental pollution [54].

\subsection{Stakeholder Analysis}

Stakeholder analysis is the process of identifying stakeholders, categorizing them, and investigating their relationships [32,55]. The identification of stakeholders is often an iterative process that uses a wide range of qualitative methods, for example, using expert opinion, focus groups, semi-structured interviews, snowball sampling, or a combination of these. During this process, relevant stakeholders are continuously added to the study [32]. But, before making such an addition and for it to be effective, the aspects and boundaries of the system in question and other related issues need to be identified [32,44,56]. Analytical categorizations, which include those using levels of interest and power [57], knowledge and attitude, cooperation and competition [58], and cooperation and threat [59], are widely used to characterize and classify stakeholders, and such analyses typically make use of matrices or Venn diagrams [32]. The power/interest grid [57] is a popular method used to classify stakeholders into four categories: players who have both interest and significant power; subjects who have an interest but little power; context-setters who have power but little interest; and crowds who have both little interest and power. Power/interest grids typically help to determine which stakeholders' interest and/or power base must be improved to address the problem at hand, as well as provide suggestions for changing stakeholders' views [55].

Complying with the key methodological steps of stakeholder analysis [32], this study started with a secondary document review to understand the context in which utilizing urban organic waste management in Hanoi has taken place. Secondary documents, such as legal regulations, national annual reports, and Hanoi municipal annual reports on solid waste management, were collected. The review of these documents focused on three main elements of the system: (i) waste separation and collection; (ii) composting; and (iii) compost use in urban agriculture. The review aimed at determining the legal framework and institutions of municipal solid waste in Vietnam and Hanoi, which is a basis for identifying stakeholders with their statutory roles in the system. Full texts of the collected relevant 
documents were read through repeatedly to understand the overall picture and to get information about specific responsibilities and coordination among stakeholders under the regulations.

Based on the review of such documents, this study then selected respondents along the vertical axis from the national level to the local level. The respondents were also chosen along the horizontal axis, covering different sectors, including administration and politics, specialized agencies in solid waste management, state management agencies in the field of agriculture, waste services companies, the general public, residents, local farmers, civil society organizations, and academics. An open list of 15 stakeholders was initially suggested in the semi-structured interview stage. The interviewees were asked to confirm the relevance of the suggested stakeholders and to carefully think about who is not but should be on the list [14]. Thus, the stakeholder list, which ultimately featured 21 stakeholders, was continuously updated with new entries, identified by the stakeholders themselves during interviews. The number of respondents for each category of stakeholders is shown in Table 3.

Table 3. Number of respondents by stakeholder category.

\begin{tabular}{|c|c|c|}
\hline Category & Stakeholders & $\begin{array}{l}\text { Number of } \\
\text { Respondents }\end{array}$ \\
\hline \multirow{14}{*}{$\begin{array}{l}\text { Governmental } \\
\text { authority }\end{array}$} & I. National level & \\
\hline & 1.Vietnam Environment Agency (VEA) & 1 \\
\hline & 2.Technical Infrastructure Agency (TIA) & 1 \\
\hline & 3. Cultivation Department (CD) & 1 \\
\hline & II. Municipal level & \\
\hline & 4. Hanoi People Committee (HPC) & 1 \\
\hline & 5. Department of Construction (DOC) & 1 \\
\hline & 6. Department of Natural Resource and Environment (DONRE) & 1 \\
\hline & 7. Department of Agriculture and Rural Development (DARD) & 1 \\
\hline & 8. Hanoi Agricultural Extension Station (AES) & 1 \\
\hline & III. District and ward level & \\
\hline & 9. People's Committee of District (PCDs) & 3 \\
\hline & 10.People's Committee of Ward (PCWs) & 3 \\
\hline & 11. Divisions of Agriculture at districts (DADs) & 3 \\
\hline \multirow{5}{*}{ Enterprise } & 12.Hanoi Urban Environment Company (HURENCO) & 1 \\
\hline & 13.Cau Dien Composting Plant (CDCP) & 1 \\
\hline & 14.Socialization Units (SUs) —Private entreprise & 3 \\
\hline & 15.Agricultural Cooperatives (ACs) & 3 \\
\hline & 16.Agricultural Inputs Stores (AISs) & 3 \\
\hline Academia & 17. Academia and research institutions & 3 \\
\hline \multirow{5}{*}{ Civil Society } & 18.Civil Society Organizations (CSOs) & 3 \\
\hline & 19. Media & 1 \\
\hline & 20. Local community (residents) & 3 \\
\hline & 21. Hanoi farmers & 3 \\
\hline & Total & 41 \\
\hline
\end{tabular}

The respondents were first asked to state their main interest, power, knowledge, and attitude towards the use of urban waste in urban agriculture through composting in Hanoi. The interviewees were then requested to give a score on these topics using a Likert scale (1-10) (Table 4). After interviews with all stakeholders were completed, data were categorized according to the inquired questions and the issues that emerged from the interviews. The categorization was assigned to the following main issues: (i) stakeholders' roles; (ii) their interests and power; (iii) their knowledge and attitude; and (iv) existing alliances. Microsoft Excel was used to organize data and construct matrices of knowledge versus attitude and interest versus power. 
Table 4. Main topics of inquiries and scoring method to evaluate stakeholders' opinion.

\begin{tabular}{|c|c|}
\hline Topics & Value Scale and Scoring \\
\hline $\begin{array}{l}\text { Knowledge-the level of understanding about the current } \\
\text { utilizing of municipal organic waste through composting }\end{array}$ & $\begin{array}{l}\text { Low knowledge (1-2.9) } \\
\text { Medium (3-6.9) } \\
\text { High (7-10) }\end{array}$ \\
\hline $\begin{array}{l}\text { Interest-the interest the stakeholder has in utilizing urban } \\
\text { waste in urban agriculture through composting }\end{array}$ & $\begin{array}{l}\text { No or minimum interest (1-1.9) } \\
\text { Limited interest }(2-3.9) \\
\text { General interest }(4-5.9) \\
\text { High interest }(6-7.9) \\
\text { Primary interest }(8-10)\end{array}$ \\
\hline Attitude-Stakeholder's opinion about the system & $\begin{array}{l}\text { Very negative }(1-1.9) \\
\text { Negative }(2-3.9) \\
\text { Neutral }(4-5.9) \\
\text { Positive }(6-7.9) \\
\text { Very positive }(8-10)\end{array}$ \\
\hline $\begin{array}{l}\text { Power-the ability of stakeholders to provide sufficient } \\
\text { resources or their ability to acquire resources in case they } \\
\text { do not have enough }\end{array}$ & $\begin{array}{l}\text { Low }(1-2.9) \\
\text { Medium }(3-6.9) \\
\text { High }(7-10)\end{array}$ \\
\hline $\begin{array}{l}\text { Coordination-the level of coordination between the } \\
\text { stakeholder and others }\end{array}$ & $\begin{array}{l}\text { Weak }(1-3.9) \\
\text { Medium }(4-6.9) \\
\text { Close }(7-10)\end{array}$ \\
\hline $\begin{array}{l}\text { Interaction-Regularity of contacts between the } \\
\text { stakeholder and others in the system }\end{array}$ & $\begin{array}{l}\text { Rare interaction } \\
\text { Quite frequent interaction } \\
\text { Frequent interaction }\end{array}$ \\
\hline
\end{tabular}

\subsection{Social Network Analysis (SNA)}

Social networks are defined as a set of nodes (or actors) that are tied by one or more types of relations [40]. Social network analysis (SNA) is the process of mapping these relationships and analyzing the structure of the network and the influence of different actors. Instead of focusing on individuals and their attributes, as is usually done in conventional methods, SNA centers on the relations between individuals, groups, or social institutions [60]. The interconnectedness of actors in social networks, therefore, has been a central focus of SNA. One of the major measures for quantifying actors' interconnectedness within social networks is centrality. The two centrality measures most widely used are degree centrality and betweenness centrality.

Degree centrality refers to how many direct connections a stakeholder has to others within the network [40,61]. This measure is valuable in identifying the actors who are likely to hold the most information or those who can quickly connect with other actors in the network. Thanks to the variety of connections they have, evidenced by their high degree centrality scores, certain stakeholders can be entrusted with the dissemination of information and mobilization of the group to action [44].

Betweenness centrality measures the number of times a node/actor lies on the shortest path between other actors $[40,61]$. This measure shows which actors act as 'bridges' between actors in a network. Thus, betweenness centrality helps to determine the node that controls the information among other nodes via connecting [44]. Lienert et al. [27] indicated that an actor with high betweenness centrality can thus act as a gatekeeper or mediator, without which the network would fall apart.

A total of 41 respondents representing the 21 above-mentioned stakeholders were interviewed (Table 3) using a semi-structured questionnaire. The design of the questionnaire, grounded on various scholarly works (see for example $[14,27,55]$ ), was developed to meet the required assessment of the stakeholders' involvement in utilizing urban solid waste in urban agriculture through composting in the specific case of Hanoi, Vietnam. The inquired main questions included the stakeholder's roles in the system, knowledge about the system, attitude towards it, level of interest, the presence of alliances related to the functioning of the system, and available resources attributed to the system. 
Also, the respondents were asked to evaluate the level of coordination between themselves and other stakeholders in the network. A score description of the main questions is shown in (Table 4). Data were then processed with UCINET software [62] to produce graphic representations and calculate the indicators of centrality.

\section{Results}

\subsection{Overview of Strategies for Recycling Municipal Organic Waste through Composting in Hanoi}

The Vietnamese government approved the amended Law on Environment in 2005, which added 14 provisions to promote the Reduce-Reuse-Recycle (3R) initiative. One noteworthy adjustment in the 2005 Law on Environment is the government's encouragement of the private sector's involvement in the provision of waste recycling services. For example, organizations and individuals that invest in the building of waste recycling facilities shall be entitled to preferential treatments of tax, credit, and land use given by the state for constructing waste recycling facilities. The Vietnam Law on Environmental Protection also states that advanced technologies for converting wastes into new materials and energy shall be encouraged, and the minimization of solid waste quantity to be disposed of in landfill sites will be a central part of waste management policy for Vietnam.

In December 2009, the National Strategy for Integrated Management of Solid Wastes until 2025 and Vision Towards 2050 was issued. The overall objective of the strategy was, on the one hand, to manage solid wastes in an integrated manner to prevent or minimize the generation of wastes at source and, on the other hand, to promote reuse and recycling so that the amount of buried waste can be reduced. By 2025, 100\% of the urban areas will have implemented household-based separation and recycling facilities for solid wastes that have been separated. Moreover, $100 \%$ of the total amount of generated urban solid waste will have been collected and processed in an environmentally friendly manner. This means that $90 \%$ should be recycled or reused for recovery of energy or production of organic fertilizers

At the city level, the municipal People's Committee of Hanoi exercised integrated management over the collection, transportation, and treatment of solid wastes in the city. Between 2006 and 2009, in the framework of the 3R (Reduce, Reuse, Recycle) program, which is financially and technically supported by the Japan International Cooperation Agency (JICA), the solid waste management authority, Hanoi City Urban Environmental Company (HURENCO), implemented a project of waste separation at the source and recycling of biodegradable waste in the four most central wards of the city, namely Lang Ha, Thanh Cong, Nguyen Du, and Phan Chu Trinh. At the beginning of the program, each household was given two types of free waste bins: an orange-colored bin for non-compostable wastes and a green-colored bin for compostable wastes. After separation, wastes were taken to Cau Dien Composting Plant to produce compost. The project was evaluated as successful in raising the awareness of citizens and significantly increasing the rate of composted organic wastes, from 7 to $30 \%$ [53]. In addition, some other pilot programs of waste separation in smaller communities have been organized in the suburban districts of the city. However, these programs are generally unsustainable. The reason is that although they remain in operation on paper, only a small number of households have continued to separate their wastes after funding for the project ran out [1].

Composting is identified as a suitable choice, given the current waste situations and socio-economic conditions of Hanoi. However, after the project concluded, the amount of recycled waste through composting remains very limited, accounting for only $2.5 \%$ of the daily household waste in the city. Currently, Cau Dien Composting Plant is the main factory chosen to perform household solid waste treatment for the metropolitan areas of the city. This plant, which was built in 1992 with a starting capacity of 30,000 tonnes of waste a year, is under the management of HURENCO. In 2002, the factory was upgraded with official development assistance (ODA) from the Spanish Government, with a treatment capacity of 50,000 tonnes of waste a year to produce 13,260 tonnes of compost fertilizer. Although it was designed for 140 tonnes of waste/day, the factory currently can only receive 
$35-40$ tonnes/day, working at $25-30 \%$ of its designed capacity, because the products it makes are not really marketable. The more the factory produces, the greater the loss it suffers, forcing it to operate on a very limited basis [2]. Apart from Cau Dien factory, which serves the central districts, Hanoi also has a smaller-scale plant-Kieu Ky Composting Plant—-tasked with the treatment of organic waste in the suburban districts of the city. However, this factory also operates only at about $27-30 \%$ of its originally designed capacity.

It is estimated that the volume of municipal solid waste in Hanoi that must be processed by 2020 and 2030 will have totaled 8500 tonnes/day and 11,300 tonnes/day, respectively [2]. Because of the urgent need to cope with these problems, Hanoi authorities have adopted the Plan of Solid Waste Treatment to 2030 with a Vision to 2050, which has been approved by the Prime Minister following Decision No. 609/QD-TTg in 2014. The promulgation of the plan aimed at minimizing the generation of solid waste right at the source while promoting reuse and recycling to ease the burden on dumping sites. It was also expected to meet the demand of the city's phase-specific collection, transportation, and treatment of waste. According to the planning, solid waste separated at the source will be in three categories: organic solid waste (vegetables, fruits, leftovers), recyclable inorganic waste (paper, plastic, metals), and other remaining solid waste. The collection and treatment processes must employ appropriate, advanced technology, especially in making compost from organic wastes, collecting energy via incineration, recycling inorganic solid wastes, and burying the remaining types of wastes properly. Also, according to the plan, Hanoi will have 17 concentrated waste treatment sites (Figure 4), eight of which will be extended and upgraded from existing sites, while the remaining nine will be new. As these 15 waste treatment facilities all have their own areas for compost production [2], there is a growing need to find markets for compost produced therein.

\subsection{Identification of Stakeholders and Their Characteristics}

The analysis of relevant reports and data collected from stakeholder interviews shows that there is a wide range of stakeholders who have been involved in, or should be involved in, municipal organic waste management in Hanoi. Applying the power-interest matrix proposed by Bryson et al. [55], this study categorizes these relevant stakeholders into four groups according to their power and interest, which were traced from the stakeholder interviews (Figure 5), as follows:

- $\quad$ Players: those having both significant interest and substantial power. This group consists of Hanoi People's Committee (HPC), Vietnam Environmental Agency (VEA), Technical Infrastructure Agency (TIA), Department of Natural Resources and Environment (DONRE), Department of Construction (DOC), and Hanoi Urban Environment Company (HURENCO).

- $\quad$ Subjects: those having an interest but little power. This group includes Cau Dien Composting Plant (CDCP); People's Committee of Districts (PCDs), People's Committee of Wards (PCWs), academia, local farmers, and local citizens (Figure 5).

- Context-setters: those having power but little interest. This group consists of socialization units (SUs) or private waste service providers, Cultivation Department (CD), Department of Agriculture and Rural Development (DARD), and Hanoi Agricultural Extension Station (AES).

- Crowd: those having both little interest and little power. This group consists of civil society organizations (CSOs), Divisions of Agriculture at Districts (DADs), agricultural cooperatives (ACs), agricultural inputs stores (AISs), and the media (Figure 5). 


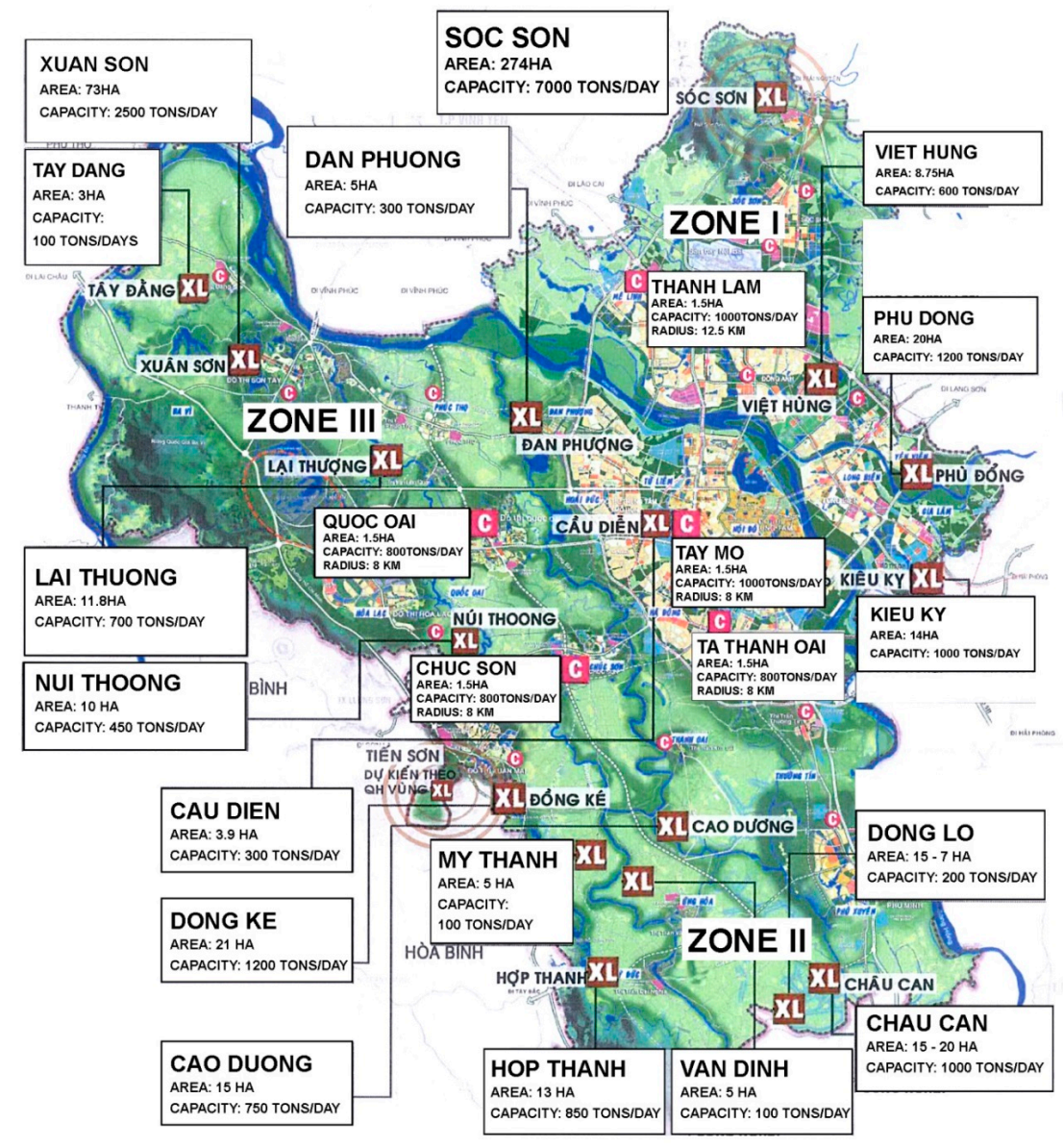

(C) Transporting point with infrastructure

(C) Transporting point without infrastructure

XL Solid waste treatment complex

Figure 4. Planning Map of Hanoi Solid Waste Treatment Complexes [2].

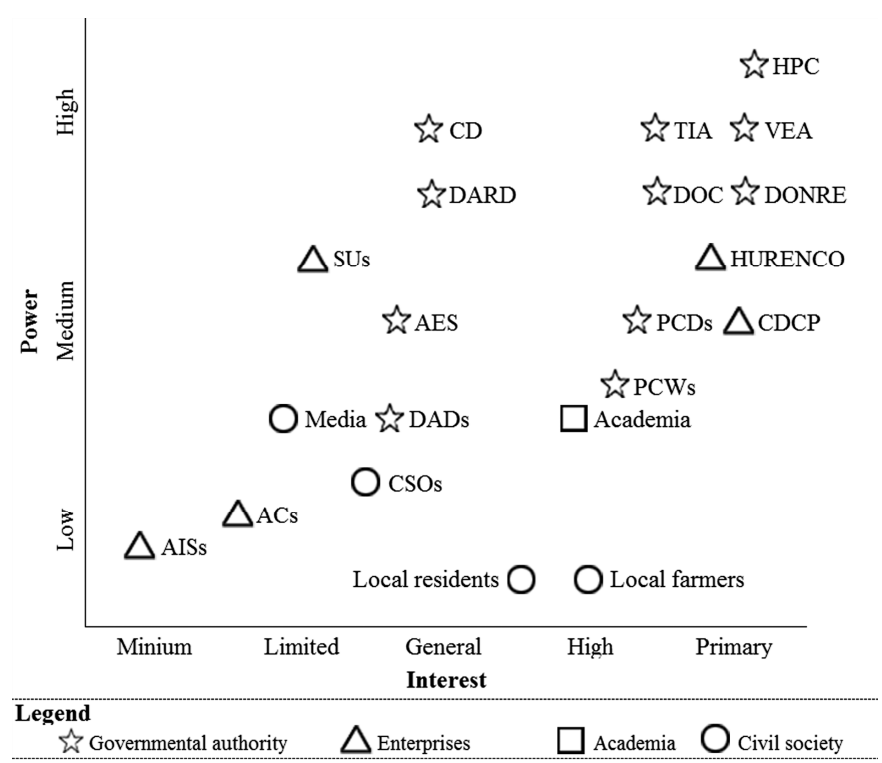

Figure 5. Power versus interest grid of stakeholders in utilizing MSW in urban agriculture. 


\subsubsection{Governmental Authorities}

Most governmental authorities are segmented into the key players group, which has both significant interest and substantial power in MSW management (Figure 5). Hanoi People's Committee (HPC) is clearly a key actor in the system that has the highest power and interest in the MSW management of Hanoi. HPC is responsible for issuing specific regulations and strategic planning for MSW management in Hanoi and providing the infrastructure, human, and financial resources. Vietnam Environment Administration (VEA) is a subsidiary body under the Ministry of Natural Resources and Environment (MONRE). With the statutory roles of a national authority, VEA belongs to the player group (Figure 5); its concerns relate significantly to the aspects of environmental pollution caused by MSW. Likewise, Technical Infrastructure Agency (TIA), which is affiliated with the Ministry of Construction (MOC), has the power to oversee and regulate practices in building the infrastructures for the implementation of waste separation and collection, as well as the construction of composting plans.

The Department of Construction (DOC) is an agency of MOC, operating under the instruction of both HPC and MOC. Regarding MSW management, DOC is mainly responsible for implementing regulations of state management on municipal solid waste management for Hanoi, including waste separation, waste collection, waste transportation, and waste treatment. The Department of Natural Resources and Environmental (DONRE) is an agency of MONRE, operating at the municipal level. DONRE plays an important role in waste management with respect to monitoring environmental quality and appraising environmental impacts for waste treatment facilities, including composting plants. DONRE is concerned with the pollution caused by the generation of solid waste and measures to avoid it. With significant interest and substantial power, DOC and DONRE are segmented into the key players group.

Agricultural management agencies, such as the Cultivation Department (CD), Hanoi Department of Agriculture and Rural Development (DARD), and Hanoi Agricultural Extension Station (AES), which belong to the context-setter group, have high power but little interest. They are responsible for agricultural development and management, of which fertilizer management is one task. CD, DARD, and AES clearly demonstrate their important roles in promoting and overseeing the use of MSW compost in the urban agricultural interface of Hanoi (Figure 5). However, stakeholder interviews with these agencies show that so far, they have not really been interested in promoting the application of MSW compost in the farming systems. The main reason, they said, was that currently, compost production is not stable, aggravated by low quality and excessive contaminants (Figure 6).

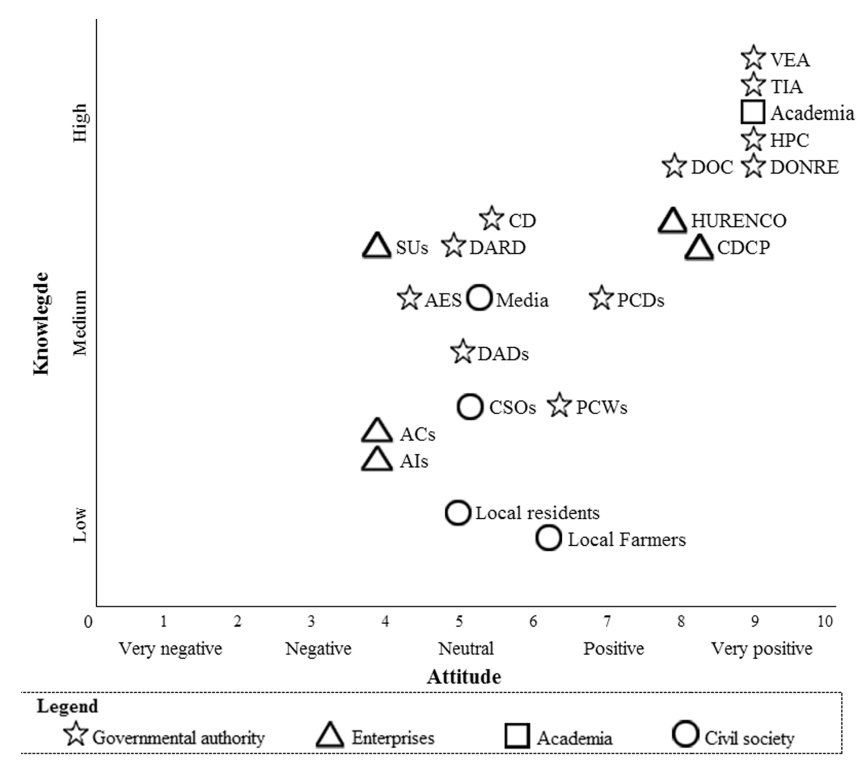

Figure 6. Attitude versus knowledge grid of stakeholders in utilizing MSW in urban agriculture. 
People's Committee of Districts (PCDs) and People's Committee of Wards (PCWs) respectively are the local authorities at the district and community levels. They are highly interested in measures to solve the increasing problems caused by MSW at their localities. However, semi-structure interviews with them indicate that they lack the human and financial resources to have direct influence on the performance of the system (Figure 5).

There is a difference in the knowledge and attitude of the policy-setting groups (HPC and governmental authorities) and the policy-affected groups (entrepreneurs, local communities, civil society organizations) (Figure 6). HPC and the regulatory governmental authorities are the group that acquires a fairly complete knowledge. During the interviews, their responses showed that they know well the elements, operations, and actors, as well as the challenges and potentials of the urban organic waste management system. With complete knowledge and a high level of power in the decision-making processes, their attitudes towards utilizing urban waste in agriculture are generally very positive (Figure 6).

\subsubsection{Enterprises}

Hanoi Urban Environment Company (HURENCO) is the only state company taking charge of waste collection, transportation, and treatment in urban districts of Hanoi city. By assignment, HURENCO is the owner of Cau Dien Composting plant—currently the biggest composting plant of Hanoi. Thus, HURENCO has a substantial interest in utilizing municipal organic waste in agriculture. However, as HURENCO is subsidized by the state budget to provide public services, it completely relies on HPC with respect to financial resources and organizational structures.

Cau Dien Composting Plant (CDCP) is a centralized plant, managed by HURENCO. $\mathrm{CDCP}$ operates the composting plant and is keen to reduce the level of environmental pollution of organic waste generated in the inner districts of Hanoi. Thus, its interest in utilizing municipal organic waste through composting is significantly high. However, $\mathrm{CDCP}^{\prime}$ s power is limited by its dependence on HURENCO and HPC for its financial resources, technology, and organizational structure (Figure 5). Recently, CDCP has been facing many difficulties in maintaining its operation. It should be noted that most of its machinery was imported from overseas at very high prices, and although the factory has not operated to its full capacity, the damaging effects of Vietnam's climate cause many machines to break down easily, while the cost of replacement and repair requires vast technical and financial support. According to the vice-director of the plant: Our company is running serious losses. The more we produce, the greater the loss is. The sale of compost is too low, mainly because its quality is not satisfactory due to failure to separate wastes at source. In addition, the unstable functioning of the machinery which results from inadequate maintenance or replacement further compounds the problem Besides, according to HURENCO, there have been no government subsidies to incentivize the recycling of organic wastes by the factory. The government has not calculated properly the cost that goes into the treatment of the volume of waste taken to the factory on a daily basis. Nor have there been any policies to encourage or support the farmers when they use compost made by Cau Dien Composting Plant.

'Socialization' of solid waste management is the term specifically used in Vietnam to indicate the participation of the private sector in the management of municipal solid waste. The socialization units (SUs) have advantages in terms of capital, technology, and human resources, which would give them significant power to influence the general system of waste management in Hanoi (Figure 5). Currently, however, most SUs are only providing solid waste collection services. They are neutral toward closing the loop of MSW in urban agriculture (Figure 6) and dismiss compost production as an unprofitable investment. In addition, they said that special supports from the municipality regarding land, taxes, credit, and market for private enterprises investing in composting remain unclear.

Agricultural cooperatives (ACs) provide multiple services to farm households, such as irrigation, fertilizers, varieties, and field protection services. They are also actively supporting agricultural extension services to farmers (e.g., application of new fertilizers, high-yielding varieties, and animal 
husbandry). Meanwhile, agricultural inputs stores (AISs) are private stores that specialize in selling agriculture-serving materials, such as fertilizers, plant varieties, pesticides, and so forth, in different localities in Hanoi. ACs and AISs have the advantage of close contacts with their clients/farmers. Thus, they could be potential active actors in promoting the use of MSW compost.

\subsubsection{Academia and Research}

Academics and research institutions, such as Vietnam National University of Agriculture, Vietnam Rural-Urban Planning Institute, and Vietnam Academy of Science and Technology, play a role in developing the system of urban organic waste management in Hanoi. Stakeholder interviews showed that academics and research institutes may not have direct decision-making power, but their views and recommendations could indirectly shape MSW management system in Hanoi, especially for mediumand long-term decisions.

\subsubsection{Civil Society}

Civil society organizations (CSOs), which have participated in local waste management in Hanoi, are mainly mass organizations, such as the Women's Union, Youth Union, Farmers' Union, and so on. When Hanoi implemented a pilot of waste separation at the source between 2006 and 2009, the extensive networks of these CSOs played a key and effective role at the community level in improving local residents' awareness of the importance of waste separation, as well as educating people to separate their household wastes properly. However, interviews with the leaders of these CSOs showed difficulties in the implementation of pilot waste separation at the source, primarily because of the low awareness and self-interested behaviors of the residents, coupled with the lack of effective regulations from the government. They remarked: "We can't afford to rely solely on the people's awareness and common sense. There need to be specific regulations and fines to force them into separating wastes at source". In fact, CSOs have limited interest and power to influence the system of MSW management in Hanoi, because solid waste management is not part of their regular duties. They lack both the financial and the human resources to maintain their support of household waste management, because the funding from the pilot projects ran out (Figures 5 and 6).

Local residents are interested in the implementation of the recycling of urban organic waste through composting (Figure 5). This is supported by a recent study by Nguyen et al. [63], which indicated that Hanoi residents showed a positive response to the separation of waste at the source. However, some of them who were participants in the pilot project of waste separation expressed an indifferent attitude (Figure 6). They did not believe that the government has had a systematic plan and process for recycling separated waste. Very often, the local people responded as follows: "If other people do not separate their wastes, then why should I?" or "Why should I separate my wastes if the authorities then merge the separated wastes all together in the same waste trucks again?"

Notably, stakeholder interviews with local farmers indicated that they were unequivocally in favor of utilizing urban organic waste in urban agriculture (Figure 6). Farmers reported that soil-inputs derived from organic matters, especially manure (pig and chicken manure) were applied by most farmers. However, presently, manure has become inadequate. Therefore, they expect that urban waste with high contents of organic matters could be a valuable soil amendment. This finding is strongly supported by the research carried out by Nguyen [64], which indicates that Hanoi farmers have a positive reaction towards compost product, evidenced by the fact that most of them are willing to buy compost if it is sold locally at a price that is similar to the price of poultry manure. However, during stakeholder interviews, farmers demonstrated concerns that compost may have low quality with a lot of contaminants (glass, weed germs, and heavy metals) that would harm their crops. They also stated that very few of them have experience with MSW compost, nor do they have any idea of where to buy it (Figure 6). 


\subsection{Network Analysis}

\subsubsection{Degree Centrality}

The involvement of a stakeholder in the system was assessed via its connectivity to others. The structural importance of an actor is mostly assessed through degree centrality, which takes into account the ties that an actor shares directly with other actors [27].

DOC and DORNE have the highest degree centrality values (Table 5), with many strong ties to all the governmental bodies (HPC, DARD, VEA, TIA) and the enterprise sector (HURENCO, SUs) in the network (Figure 7). With the high values of degree centrality, these actors have better and more direct access to information and thus play important roles in operating the system. However, the current link between DOC and DONRE, as well as the alliance between these two agencies with other actors, focused only on the waste collection and disposal processes. HURENCO, with the role of a state enterprise, is central, given its strong ties to HPC, DOC, and Cau Dien Composting Plant. HURENCO also works closely with PCDs and PCWs when it is providing solid waste services (Figure 7, Table 5). Compared with HURENCO, private enterprises (SUs) are not as directly connected to others in the network (Figure 7, Table 5). Interviews with managers of SUs indicate that they do not have any cooperation with other stakeholders with regard to the utilization of urban wastes in urban agriculture. They are sub-contracted or employed with the basic mandate of collecting waste from residential households, clearing the waste off the streets, and transporting it to designated dumpsites. Their sole interest is in doing the tasks they are paid to do as specified in their contracts.

Table 5. The importance of stakeholders based on degree centrality measure.

\begin{tabular}{cccc}
\hline \multicolumn{1}{c}{ Stakeholders } & & \multicolumn{2}{c}{ Degree Centrality } \\
\hline Name of Stakeholders & Abbreviations & Value & Rank \\
\hline Department of Construction & DOC & 9.000 & 1 \\
Department of Natural Resource and Environment & DONRE & 9.000 & 2 \\
Hanoi People Committee & HPC & 7.000 & 3 \\
Hanoi Urban Environment Company & HURENCO & 7.000 & 4 \\
Department of Agriculture and Rural Development & DARD & 7.000 & 5 \\
People's Committee of District & PCDs & 6.000 & 6 \\
Divisions of Agriculture at districts & DADs & 6.000 & 7 \\
People's Committee of Ward & PCWs & 5.000 & 8 \\
Agricultural Cooperatives & ACs & 5.000 & 9 \\
Hanoi Agricultural Extension Station & AES & 5.000 & 10 \\
Farmers & & 5.000 & 11 \\
Vietnam Environment Agency & VEA & 4.000 & 12 \\
Cau Dien Composting Plant & CDCP & 4.000 & 13 \\
Civil Society Organizations & CSOs & 4.000 & 14 \\
Socialization Units & SUs & 4.000 & 15 \\
Media & & 4.000 & 16 \\
Cultivation Department & CD & 3.000 & 17 \\
Technical Infrastructure Agency & TIA & 3.000 & 18 \\
Agricultural Inputs Stores & AISs & 3.000 & 19 \\
Academia & & 2.000 & 20 \\
Local community (residents) & & 2.000 & 21 \\
\hline
\end{tabular}

In its capacity as a compost-producing company, Cau Dien Composting Plant should play a central role in the system. However, the plant is not well-connected with other actors in the network, and its current cooperation with several other actors is not significant either (Figure 7). Moreover, the academics are not well-positioned in the network and are the least directly connected to others, with only tenuous links to some specialized agencies (CD, VEA). Lastly, the local community and farmers, who decide whether or not waste are separated and if compost is to be used as a soil amendment, are, in fact, isolated (Figure 7, Table 5). 


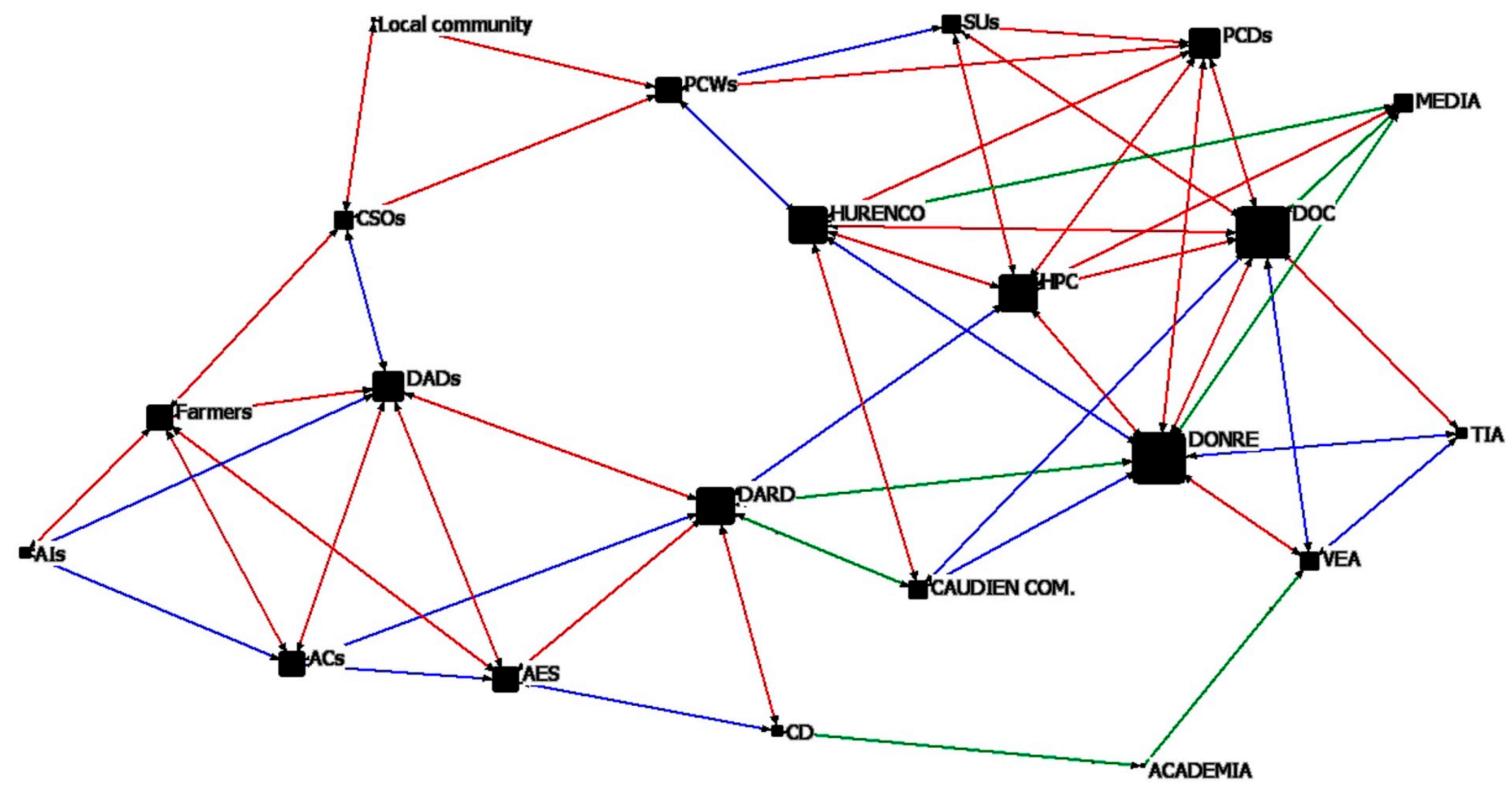

Figure 7. Coordination network—Degree centrality. (Note: The size of each node positively correlates with the degree centrality value (larger node indicates higher degree). Weak ties: green lines; medium ties: blue lines; and close ties: red lines. 


\subsubsection{Betweenness Centrality}

The importance of relational patterns among actors in the network can be assessed through betweenness centrality that calculates the total number of times an actor is on the path between two nodes that are not interlinked. An actor with high betweenness centrality can thus act as a mediator, without which the network would be fragmented [27].

The results of the betweenness centrality analysis presented in Table 6 and Figure 8 largely confirm the insights gained when assessing degree centrality-two state management bodies, which are responsible for municipal solid waste management, namely DOC and DORNE, are central in the overall network and act as mediators to connect other actors.

Table 6. The importance of stakeholders based on betweenness centrality measure.

\begin{tabular}{cccc}
\hline Stakeholders & & \multicolumn{2}{c}{ Betweeness Centrality } \\
\hline Name of Stakeholders & Abbreviations & Value & Rank \\
\hline Department of Agriculture and Rural Development & DARD & 58.977 & 1 \\
Department of Natural Resource and Environment & DONRE & 33.937 & 2 \\
People's Committee of Ward & PCWs & 25.018 & 3 \\
Divisions of Agriculture at districts & DADs & 19.617 & 4 \\
Civil Society Organizations & CSOs & 18.411 & 5 \\
Department of Construction & DOC & 17.792 & 6 \\
Hanoi People Committee & HPC & 17.190 & 7 \\
Hanoi Urban Environment Company & HURENCO & 13.821 & 8 \\
Vietnam Environment Agency & VEA & 10.708 & 9 \\
Hanoi Agricultural Extension Station & AES & 10.375 & 10 \\
Cultivation Department & CD & 8.792 & 11 \\
Agricultural Cooperatives & ACs & 8.544 & 12 \\
People's Committee of District & PCDs & 7.341 & 13 \\
Farmers & & 7.011 & 14 \\
Cau Dien Composting Plant & CDCP & 4.254 & 15 \\
Socialization Units & SUs & 3.712 & 16 \\
Academia & & 2.500 & 17 \\
Technical Infrastructure Agency & TIA & 0.000 & 18 \\
Local community(residents) & & 0.000 & 19 \\
Media & & 0.000 & 20 \\
Agricultural Inputs Stores & AISs & 0.000 & 21 \\
\hline
\end{tabular}

Moreover, it is important to note that DARD has the highest betweenness centrality value. DARD is the only actor that, on the one hand, approaches or works closely with other actors in the field of agriculture, such as CD, DADs, ACs, and AES, and, on the other hand, coordinates with other major actors, such as DONRE, HPC, and Cau Dien Composting Plant (Figure 8). Notably, however, the coordination between DARD and agencies, such as DONRE and HPC, is not directly related to the management of urban organic waste. Instead, this coordination is vital to the management of crop waste that is generated from farming activities in suburban areas of Hanoi. The only direct link that DARD has (regarding the management of urban organic waste) is its coordination with Cau Dien Composting Plant in checking, evaluating, and licensing the compost products made by the plant. This lack of coordination accentuates the fragmentation of the system. 


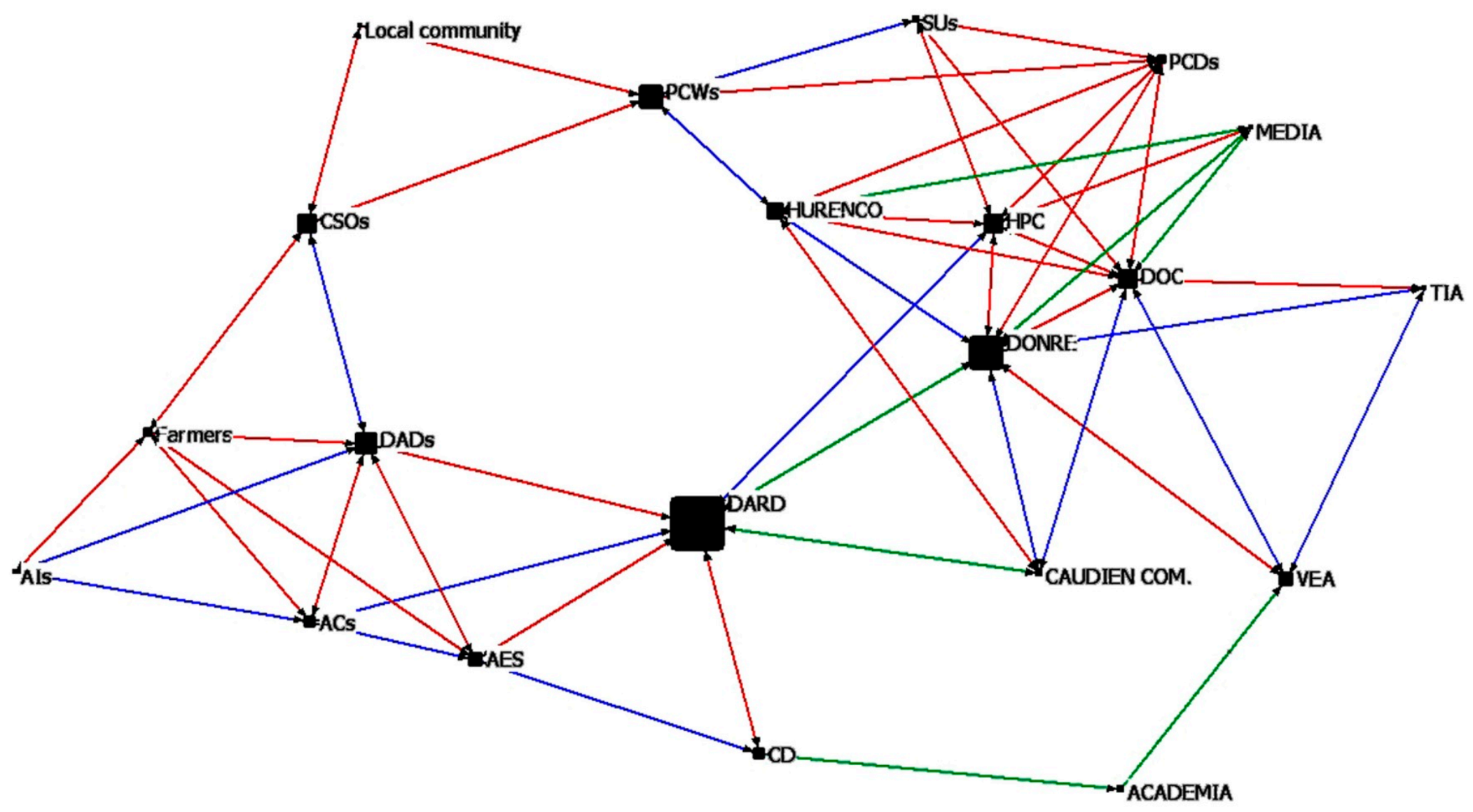

Figure 8. Co-ordination network-Betweenness centrality. (Note: The size of each node positively correlates with the betweenness centrality value (larger node indicates higher betweenness centrality). Weak ties: green lines; medium ties: blue lines; and close ties: red lines. 
Moreover, the coordination between different actors in the current system is mainly top-down, performed vertically from the specialized agencies at the central level (CD, TIA, VEA) to the departments at the provincial level (DARD, DOC, DONRE). These agencies are under the state management of the municipal people's committee (HPC) and are asked to perform specialized functions at the district level, and from district level down to the community level. There is very little intersectoral or horizontal coordination performed, apart from some links between DORNE, DOC, and DARD. However, even these links are usually loose and irregular, as can be seen in Figure 8 . Likewise, with very low betweenness centrality values, SUs, TIA, CD, Cau Dien Composting Plant, farmers, the media, and the academics are peripheral to, and not embedded in, the network (Table 6 and Figure 8). The findings clearly highlight the horizontal fragmentation across sectors.

\subsection{Comparing Systems of Municipal Solid Waste Use in Agriculture through Composting in Hanoi and Other Asian Countries}

While circumstances can vary significantly from one Asian country to another, there are certain similarities in their municipal solid waste management $[65,66]$. Increased municipal solid waste, which is associated with a burgeoning urban population and economic growth, proves challenging to both developed and developing countries in the region. Waste collection rates remain well below full-service coverage, despite many Asian cities' estimated spending of $20-50 \%$ of their annual budget on the management of municipal solid waste [67], for which the composition is usually dominated by organic waste [4]. The practice of shopping in traditional markets and the importance accorded to family meals in the vast majority of Asian countries explains the dominance of organic waste in this region. Composting, therefore, is the most commonly applied method of waste management in Asian countries, and it is seen in applications that range from household-scale to large, centralized plants [4,39]. Currently, however, separation at the source is not yet a common practice in Asia and represents a critical area for improvement [4]. Mixed waste is clearly the main problem related to organic waste management in the region. To reduce the disposal of organic waste into landfills, various recycling strategies have been implemented in the region. Not all of them have proved to be successful, however [68]. This section draws on a comparison between Hanoi and other Asian countries in terms of organic waste management in order to determine factors influencing the possibility of linking urban waste to agriculture through composting. The varied practices of composting based on municipal organic waste management are summarized in Table 7.

Given the nature of solid waste management as a public service, institutional and legislative support is a precondition for successful performance of MSW management systems [16,39]. The cases of Taiwan and South Korea both illustrate the critical role of a comprehensive legal framework in creating a recycling-oriented society. Taiwan's recycling efforts can be traced back to the Waste Disposal Act, which was promulgated in 1974 and has since been amended nine times to include very specific regulations, such as pay by bag collection fee, mandatory MSW sorting, extended producer responsibility, the 4-in-1 program, and so on [7,69]. Similarly, in South Korea, based on the Waste Control Act, the government issued effective regulations and policies, such as the volume-based food waste fee system, mandatory waste separation at the source, and extended producer responsibility, and so forth. As a result, Taiwan and Korea have had outstanding performances in resource recycling promotion (Table 7). Meanwhile, in the cases of Hanoi and Bangkok, although there are laws on environmental protection and national regulations regarding sustainable MSW management, specific regulations to encourage and enforce stakeholders' responsibilities for solid waste management at local levels are generally lacking. As a consequence, these cities are still facing severe problems due to low stakeholder participation in all the different stages of utilizing urban organic waste in agriculture. The recycling of mixed waste in the cases of Hanoi, as discussed above, and of Bangkok, shown in Table 7, has led to low-quality compost, which in turn could increase the operational cost and worsen marketability problems. This was also a reason for the collapse of many composting plants throughout the region [4]. The successes in the cases of Taiwan and South Korea in the segregation of 
waste (Table 7) suggest that separation at the source should be mandatory with effective enforcement measures, such as the refusal to collect unsorted waste and imposing fines on violators. At the same time, the application of economic incentives, for example, the implementation of the "pay per bag" scheme in Taiwan for general waste and free-of-charge collection of food waste and recyclables, or the policy of volume-based food waste fee in South Korea, which means households have to pay for the quantity of food waste they generate, could facilitate positive changes in household behavior (Table 7).

In addition, technical conditions including technology, equipment, and infrastructure for the adequate storage and collection of separated wastes, as well as sufficient transportation and recycling plants (in this case composting plants) also play a decisive role in the performance of the system of organic waste management in these countries. The realities in Hanoi and Bangkok show that people soon became discouraged from separation programs upon learning that separated and non-separated waste are mixed together and carried to dumping sites on the same garbage truck. That is not to mention the ineffective operations and gradual close-down of many recycling plants $[63,70,71]$ because of financial reasons. In Taiwan and South Korea, financial conditions are met by the adoption of the Extended Producer's Responsibility initiative, which requires producers/enterprises to take responsibility for the separation, collection, and recycling of their products after consumption. However, companies do not necessarily have to collect and recycle waste themselves. Instead, they can pay fees to the Resource Recycling Management Fund, which is then used to promote the separation, collection, recycling, and burial of waste (Table 7). In addition, South Korea and Taiwan have applied the polluter pays principle, which forces the person who discharges waste, depending on the amount, to pay the collection and treatment costs. This scheme helps to increase the funds for MSW management and, at the same time, motivates people to reduce waste, thus easing the financial and technical pressure of waste management. Meanwhile, in Vietnam and Thailand, waste collection and disposal services are paid via flat taxes/fixed charging that are unrelated to the volume of waste produced. This unfortunately leads to excessive waste generation, as dischargers do not have to pay for any extra units of waste. More than half of the regional counties' budgets are spent on urban waste management, most of which, however, goes to the collection of waste [67].

Also, the practices of Taiwan and South Korea, in the cases presented in Table 7, demonstrate that consensus and active participation of the relevant stakeholders is critical for success. In these countries, practices of good governance are reflected by the co-management and negotiation of information and knowledge within and across levels. In the case of Taiwan, it is clear that various stakeholders, state and non-state alike, are engaged in the MSW management system. The Taiwan Environmental Protection Administration (EPA-a cabinet-level executive agency responsible for governing the environment) and the local EPAs affiliated with it work with municipal administrators, private and public enterprises, the academia, environmental Non-Governmental Organizations (NGOs), residents, and other stakeholders to control how waste resources are sorted, reused, and recycled into new products. Likewise, South Korea has been successful in building consensus among the academia, relevant institutions, agriculture development agencies, enterprises, and civic groups on food waste issues (Table 7). 
Table 7. Practice of municipal organic waste management in some Asian countries.

\begin{tabular}{|c|c|c|c|}
\hline Country/City & Performance and Results & Stakeholders' Involvement & Source \\
\hline $\begin{array}{l}\text { Taiwan, } \\
\text { China }\end{array}$ & $\begin{array}{l}\text { 1974: Solid Waste Disposal Act was promulgated. } \\
\text { - } \quad \text { 2002: Resource Recycling Act became effective. } \\
\text { - } \quad \text { 2005: a compulsory waste separation at the source program was deployed. } \\
\text { - } \quad \text { Recyclables and food waste separated by households are collected free of charge. } \\
\text { - } \quad \text { Collecting workers have rights to reject the unseparated solid waste. } \\
\text { - } \quad \text { Any household that fails to separate waste will be subject to fines ranging } \\
\text { between } 1200 \text { and } 6000 \text { Taiwanese Dollars. } \\
\text { - } \quad \text { A pay-by-bag collection fee system for general wastes was applied. } \\
\text { - } \quad \text { Extended Producer's Responsibility Initiative was started. } \\
\text { - The 4-in-1 program was run. } \\
\text { - } \quad \text { The construction of composting plants was subsidized. } \\
\text { - } \quad \text { MSW per capita per day decreased from } 1.143 \text { to } 0.397 \mathrm{~kg} \text { in } 2012 . \\
\text { - The resource recycling rate in Taiwan has increased from } 5.88 \% \text { in } 1998 \text { to } 53.94 \% \\
\text { in } 2012 .\end{array}$ & $\begin{array}{l}\text { Local residents: } \\
\text { - } \quad \text { Form community-based recycling organizations. } \\
\text { - } \quad \text { Promote separation of waste and recycling. } \\
\text { - } \quad \text { Purchase waste resources from the public, } \\
\text { communities, and local government. } \\
\text { Local government: } \\
\text { - } \quad \text { Collect and transport separated waste. } \\
\text { - } \quad \text { Environmental Protection Administration (EPA) } \\
\text { staff randomly checks residents' waste bags at } \\
\text { collecting points. } \\
\text { Instruct people how to sort their wastes properly. } \\
\text { EPA and its local EPAs have cooperated with } \\
\text { environmental NGOs. } \\
\text { Recycling Fund: } \\
\text { - Get paid by responsible enterprises. } \\
\text { - Use the Fund to subsidize the recycling and } \\
\text { disposal system. }\end{array}$ & $\begin{array}{l}\text { Chen [7]; } \\
\text { Chen et al. [29]; } \\
\text { Houng et al. [69]; } \\
\text { Chen and Chang [72]; } \\
\text { Lu et al. [73]. }\end{array}$ \\
\hline
\end{tabular}


Table 7. Cont

\begin{tabular}{|c|c|c|c|}
\hline Country/City & Performance and Results & Stakeholders' Involvement & Source \\
\hline South Korea & $\begin{array}{l}\text { 2005: food waste was banned from landfills. } \\
\text { - 2010: a project of food waste reduction was implemented. } \\
\text { 2010: mandatory recycling of food waste and the policy of volume-based food } \\
\text { waste fee was implemented, which means households have to pay for the } \\
\text { quantity of food wastes they generate. } \\
\text { - Promoted Extended Producer's Responsibility. } \\
\text { - Recycling sectors are given capital supports to treat food waste as } \\
\text { productive resources. } \\
\text { - A policy of using compost to replace chemical fertilizers was issued. } \\
\text { - Inspection is carried out twice a year by analyzing } 700 \text { samples of MSW compost, } \\
\text { of which } 200 \text { samples are randomly selected at production sites. } \\
\text { - The composting of industrial waste and the selling of immature compost are to be } \\
\text { strictly prohibited. } \\
\text { Practical guidebooks are available to instruct the application of compost to } \\
\text { different farming crops. } \\
\text { The food waste recycling rate is more than } 90 \% \text {. Of the recycled food waste, } 50 \% \\
\text { is transformed to compost fertilizers. }\end{array}$ & $\begin{array}{l}\text { The government: issued laws and specific } \\
\text { regulations; implemented education and publicity } \\
\text { campaigns in collaboration with NGOs; and } \\
\text { established the Food Waste Forum. } \\
\text { Restaurants, hotels, school, offices, and } \\
\text { households were encouraged to volunteer to } \\
\text { participate in food waste reduction. } \\
\text { The Rural Development Administration (RDA) } \\
\text { holds the main responsibility for quality } \\
\text { inspection of MSW compost. } \\
\text { - Producers pay a recycling and disposal fee to the } \\
\text { Recycling Fund. } \\
\text { The consumer bears part of the recycling costs } \\
\text { that are reflected in the price of products. }\end{array}$ & $\begin{array}{l}\text { Um and Lee [74] } \\
\text { Min and Rhee [75]; } \\
\text { Lee and Paik [76] }\end{array}$ \\
\hline $\begin{array}{l}\text { Bangkok, } \\
\text { Thailand }\end{array}$ & $\begin{array}{l}\text { 1997-2016: The Government implemented an environmentally sound waste } \\
\text { disposal system and improved waste disposal capacity of local } \\
\text { government agencies. } \\
\text { In 1997, Bangkok Metropolitan Administration (BMA) started the source } \\
\text { segregation program. } \\
\text { Waste segregation at the source has not been practiced because the collection } \\
\text { system to receive separated waste source for treatment is not well-maintained, } \\
\text { and economic incentives, as well as legal tools, are not significant to adjust } \\
\text { residents' behaviors. } \\
\text { 2007-2016: BMA adopted various plans and strategies, such as the } \\
\text { Reduce-Reuse-Recycle (3Rs) program, which improved the waste collection } \\
\text { system and community-based solid waste management. However, these } \\
\text { strategies are not as successful as planned due to limited resources, political } \\
\text { conflicts, and lack of awareness and cooperation from residents. } \\
\text { Pollution Control Department published a guideline on composting in } 2004 \text { to } \\
\text { promote the composting of urban organic waste. } \\
\text { BMA have signed subcontracts with private companies to operate large-scale } \\
\text { composting plants. However, the composting process affected by mixed waste } \\
\text { resulted in low-quality compost. }\end{array}$ & $\begin{array}{l}\text { - BMA paid more attention to the improvement of } \\
\text { final disposal rather than segregation } \\
\text { and recycling. } \\
\text { Recycling practices are dominated by informal } \\
\text { participation (waste pickers and tricycle } \\
\text { waste buyers). } \\
\text { Local government has little interaction } \\
\text { with citizens. } \\
\text { - Mistrust prevents people from practicing source } \\
\text { separation in Bangkok. } \\
\text { - Public participation in source separation and } \\
\text { recycling is low. }\end{array}$ & $\begin{array}{l}\text { Sukholthaman, et al. [77]; } \\
\text { Sharp and Sang-Arun [71]; } \\
\text { Siriratpiriya [78]; } \\
\text { Manomaivibool [70]; } \\
\text { Vassanadumrongdee and } \\
\text { Kittipongvises [79] }\end{array}$ \\
\hline
\end{tabular}




\section{Discussions}

\subsection{About the Case Study of Hanoi, Vietnam}

Similar to other developing cities in the region, organic waste in Hanoi accounts for the largest proportion of municipal solid waste. This is increasing rapidly along with higher economic growth and rapid urbanization. The government of Vietnam has developed an overall legal framework to make sure that daily waste is separated at the source and organic waste is treated through composting to deal with the overloaded dumping grounds while reducing greenhouse gas emissions to the environment. However, this framework does not appear to have worked well in Hanoi. The comparison between Hanoi and other Asian countries regarding organic waste management suggests that both technical and non-technical factors, such as institutional and legislative support, as well as financial conditions, level of interest, and active involvement of stakeholders can determine the effectiveness of the systems of recycling organic waste through composting. The combination of SA and SNA in this paper helped to evaluate these non-technical conditions in the case study of Hanoi, Vietnam.

SA indicated that policy-setting groups (governmental authorities and HPC) acquire fairly significant interest and power, and their attitude towards utilizing MSW in agriculture is generally very positive. Meanwhile, the policy-affected groups (composting plants, local residents, farmers, the academia, and civil society organizations) have substantial interest but very little power to have any influence on the existing system. They were actually judged as potential stakeholders. Similar results were found in the management of organic waste through composting in Bangkok. On the contrary, in Taiwan and South Korea, these stakeholders were effectively involved and took part enthusiastically, in the separation, collection, recycling, and reuse processes (Table 7). SNA showed that hierarchical governance arrangements dominate MSW management in Hanoi. The national legal framework for the integrated management of solid waste is being converted into Hanoi's implementation of MSW management in a largely top-down manner. This is reflected in the present performance of Hanoi's MSW management. The departments at the municipal level (DARD, DOC, and DONRE) are under the management of Hanoi People's Committee (HPC) to perform the specialized functions in MSW management at the municipal level and assign specific duties to the district and community levels (Figures 7 and 8). At the same time, a combination of SA and SNA revealed that other relevant stakeholders including the academia, the media, enterprises (CDCP, SUs, ACs, AIs), and the community level (CSOs, residents, local farmers) were perceived as being less important (Tables 5 and 6 ) and were not well embedded in the network. This practice shows a lack of horizontal cooperation among the sectors at all levels of governance, thus confirming network fragmentation (Figures 7 and 8).

This network fragmentation can be elucidated by data collected from SA. Interviews indicated that policies and regulations are not devised particularly for the management of organic waste; they only aim at municipal solid waste in general. As a result, the municipal authorities of Hanoi-HPC and relevant responsible agencies, such as DOC and DORNE, affiliated with HPC - have done no more than collect and safely dispose of wastes without any significant efforts to separate and compost them. While specialized agencies in agricultural production management, such as CD, DARD, AES, and DADs, are fully aware of the long-term and sustainable benefits of organic matter in urban waste towards the improvement of farming soil quality, they have not paid sufficient attention to improving, introducing, and applying compost in agricultural production. Similarly, all businesses, be they public (HURENCO) or private (SUs), tend to prioritize short-term benefits by focusing on collection and disposal while usually at the expense of projects for separation and recycling. The lack of legal tools results in the pursuit of short-term rather than long-term benefits. This finding was strengthened by the comparison of utilizing urban waste in agriculture between Hanoi and other Asian countries. The success of Taiwan and South Korea presented in Table 7 indicates that an effective legislation framework is essential to adjust the behaviors of relevant stakeholders. Conversely, the inadequate legislations are destructive to the performance of a sustainable municipal solid waste management system, especially in developing countries $[16,80]$. 
In addition, SA indicated that lack of trust was another reason for the general disinterest and indifference of many of relevant stakeholders and, consequently, the weak coordination among stakeholders. Trust among stakeholders can be shattered if parties blame one another for failure. Interviews indicated that the local authorities blame the people for a lack of common sense, stating that incorrect disposal of waste remains omnipresent, and old habits are difficult to change. The people, on their part, complain about the government's inadequate investment, the lack of governance capacity, the absence of a strategic plan to carry out separation, and the paucity of a technical infrastructure to deal with already-separated waste. The state-owned enterprise HURENCO also complains of the financial constraints and the inadequacies in the management of solid wastes from the central to local levels. Meanwhile, private companies speak out against the lack of incentives from the local authorities in terms of land, infrastructure, and capital to support their enterprises; they also mention the discrimination between the public and private sector in almost all aspects, including administrative procedures. These results suggest that the interests of one party cannot be achieved without reliance upon another and lack of trust hinders cooperation. The finding is consistent with previous empirical evidence that has been found in several studies regarding the relation between trust and cooperation in solid waste management [63].

Moreover, the results from the interviews with different stakeholders showed that the participation of private enterprises (SUs) remains extremely limited, both in quantity and scope, and focuses only on the collection and transportation part of the process while investment in recycling has been missing. Network analysis showed that SUs were located peripherally with weak ties to other actors. MSW management clearly lies in a multifaceted space between private and public goods [5]. For the MSW management to work properly at low cost while still maintaining satisfactory quality, it is necessary to strengthen the partnership between state and non-state actors, especially the active involvement of private enterprises [80].

\subsection{About the Methodology}

A wide variety of tools and approaches have been used for the evaluation of stakeholders' participation in environmental management $[32,81,82]$. Previous studies have tended to resort to purely qualitative methods, such as focus group, semi-structured interview, direct observation, interest-influence matrices, historical and trend analyses, and so on, to identify stakeholders and analyze relations among them. Qualitative methods, which use nonnumeric data to understand stakeholder's perceptions, experiences, and beliefs, prove to be useful in discovering and identifying local problems [32,82]. However, qualitative research also has its own limitations [32,81,82]. Therefore, a combination between qualitative and quantitative methods, known also as the mixed method, is becoming increasingly popular in many scholarly works about environmental resource management $[49,50]$.

The combination of SA and SNA in this paper offers a typical example of the mixed method model. The aim of this study is to see how actors representing different levels and sectors are integrated into the processes of linking urban waste to urban agriculture. Normally, a research problem of this type can be resolved through the method of stakeholder analysis [32,83]. However, recent evidence in research on environment or natural resource management has shown that this approach is not always reliable, especially in assessing the relations among stakeholders that crisscross different levels and sectors $[27,83]$. With different actors and sectors taking part in the municipal solid waste management, there needs to be a method to investigate their relationships. A combination of stakeholder analysis and social network analysis is useful in investigating such multilevel governance settings. The methodology applied was appropriate to translate a holistic approach into practice. An already established system of utilizing urban waste in agriculture was evaluated in a different way with network perspective.

While SA focused on the characteristics of stakeholders, SNA clarified the structure of relationships between those stakeholders. SNA not only allowed the present study to assess the stakeholders' connections by providing the mappings of the network, but also helped to identify 
the structural importance of each stakeholder as well. The network nodes were characterized by types (government, private company, civil society, media, academia, etc.); the network ties expressing stakeholders' coordination levels were evaluated by prompting stakeholders to give scores. Moreover, this study highlights the role of SA in explaining the limitations of the present network. Weak legislative framework, distrust, technical and financial constraints, and limited participation of private enterprises were underscored by SA. These results are crucial in explaining the tenuous connections among stakeholders and the network fragmentation that were identified by SNA. The combined effects of qualitative and quantitative analyses appear to help shed more light on the research question than if used separately. Inferences can become more valid if one set of results can be tested by and cross-checked with another [14]. However, compared with the single method, this combination also has weaknesses with regards to budget and time constraints [50]. Moreover, it also requires the researchers to be competent and skilled in conducting both qualitative and quantitative analyses.

\subsection{About Policy Recommendation}

The research findings offer a wide range of recommendations for the development of a strategic plan to encourage the compost-based utilization of municipal solid waste in agriculture. The results showed a lack of horizontal cooperation among the sectors at all levels of governance, thus confirming the fragmented nature of the network (Figures 7 and 8). Therefore, a strategic plan for sustainable management of municipal organic waste should be designed to mobilize the engagement and contribution of all participants including the central government, municipality, waste management officials, private and non-private enterprises, agriculture management agencies, local residents, compost users, the media, and research institutions. At the same time, the strategic plan should deal with all parts of the system, including waste separation and collection, composting, and compost use. The following critical aspects need to be taken into account in the process of strategic planning of organic waste utilization in agriculture in the setting of Hanoi.

The research findings showed that the absence of specific guidelines and regulations for the operation of the system is the key factor that prevents the stakeholders from fully executing their roles. In addition, lack of trust was another reason for the tenuous coordination among the stakeholders. Therefore, top priorities should be given to a legal framework with specific regulations. Moreover, regulations should be actually enforced and applied consistently and fairly to mobilize effectively the participation of relevant stakeholders while helping to build trust that is crucial to an improved cooperation among the stakeholders. As in many other environmental situations, one of the key barriers to utilizing MSW in agriculture is social dilemma [64,84]. The fundamental question concerning how defection problems are resolved has been addressed in various studies on common dilemmas in waste separation and recycling $[63,85,86]$. Interviews indicated that people will not separate waste unless they know that other members in the community will also do the same. On the other hand, when interactions are repeated, the level of cooperation may go up if one believes that those who violate the regulation will be penalized. In such case, an explicit sanction scheme could be considered to enhance the level of cooperation and at the same time prevent defection. The use of penalties has also proved to be effective in the cases of Taiwan and South Korea in increasing the level of household participation in organic waste recycling programs (Table 7).

It is evident that linking urban waste to agriculture through composting is only feasible if its end-product, compost, is accepted by farmers who are the end-users. Interviews with Hanoi farmers suggest that concern about compost's quality is the main reason for farmers' propensity to hesitate to adopt compost. This result is in line with the previous literature, which indicates that farmers typically tend to avoid taking risks and are reluctant to adopt innovations that have not been time-tested $[87,88]$. Therefore, on-farm trials would be a helpful policy to demonstrate the advantages of compost, as well as reassure farmers of the safety and quality of compost. Moreover, insurance policies for farmers using compost should be considered in the first period of application. There is also a need to establish specific regulations for compost quality standards to manage its quality and minimize risks for farmers. 
Furthermore, most waste management services (separation, collection, transportation, and composting) should be regarded as a kind of private goods with preferential treatment in terms of capital, land, tax, and infrastructure to encourage the private sector (SUs) to invest in all the stages of separation, collection, and recycling instead of stopping at only collection, as is the case currently. There needs to be a mechanism to enable composting plants to benefit from the tangible and intangible contributions they make to the city. An enabling environment for private sector participation in MSW management can only be created once there has been an established guideline for public-private partnership (PPP).

In addition, it has also been pointed out in the research that the critical problem of the system is the heavy financial losses suffered by composting plants due to failure to sell the produced compost. Regarding the promotion of compost use, the government-particularly specialized agencies in the field of agricultural management, as they belong to the context-setter group with high betweenness centrality values (Figures 5 and 8 ) —need to play a more important role in improving testing quality and promoting compost application in agricultural systems, thereby developing the market for compost. Furthermore, it is also necessary for composting plants to work with Hanoi Agricultural Extension Station (AES), as well as with the network of agricultural cooperatives (ACs) and the network of agricultural inputs stores to market and sell compost products. Moreover, the cooperation between the composting plants and fertilizer-producing companies could help solve the problems of quality and marketing, which in turn will ease the financial constraints for the composting plants [5].

Market solutions for compost, however, can only be viable if compost is produced with good quality. Therefore, due attention must be paid to the finished compost right from the design stage for any successful system of compost-based utilization of MSW in agriculture. In the absence of a reliable method to identify and separate the materials in the mixed waste, it is very difficult to ensure low contaminant levels, which is essential for the production of good-quality compost. For the time being, source segregation remains the key to improved performance. To promote source segregation, technical supports, including improved equipment and infrastructure, need to be provided to facilitate waste separation through the use of necessary separation facilities, means of transportation, and equipment, such as waste bins, plastic bags, and so on, in order to remove the practical difficulties confronted by residents in previous pilot programs. It is also necessary to promote the intermediary role of the media and the academia in connecting the governmental authorities, waste service providers with the local residents, farmers, and civil society organizations whose strengthened information exchange can help raise the awareness and build confidence among different parties in the entire system.

\section{Conclusions}

Utilizing MSW in agriculture is characterized by complex interactions between different levels and sectors. This study adopted the approach of multilevel governance to investigate the specific features of each of these stakeholders, as well as their interdependence in the respective local settings. A combination of stakeholder analysis and social network analysis was deemed appropriate to evaluate an already established system of utilizing urban waste in agriculture in Hanoi, Vietnam.

According to the results of SA, stakeholders express a significant interest in recycling MSW through composting. However, many of them do not have sufficient power to make any changes to the current system. This imbalance of the power and interest among stakeholders resulted from the fact that only the local authorities, HPC, together with two specialized agencies affiliated with it (DONRE and DOC) are tasked with the responsibility of managing MSW in Hanoi, without close coordination with other stakeholders. Moreover, although the local governmental stakeholders (DOC and DONRE) are certainly the key players in the system due to high interest, power, and degree of centrality values, they have only been involved in the collecting, transporting, and disposing of waste without making substantial efforts in separating and composting it. Meanwhile, the other players, such as agencies in agricultural production management (CD, DARD, AES), have not paid significant attention to introducing and promoting compost in agriculture. Moreover, the community level (PCWs, CSOs, 
local residents, and farmers) and the intermediary parties (the academia and media) were only judged as potential, instead of actual stakeholders. Therefore, incentive policies need to be designed to allow the potential key players to get involved in the system.

SNA helped to assess the stakeholders' connections. The analyses of degree and betweenness centrality values showed that there is a lack of connection among stakeholders. It is critical to see that the cooperation among the stakeholders is mainly realized in a hierarchical manner without adequate horizontal interactions, leading to apparent network fragmentation in the system. This fragmentation can be attributed to the weak legislative framework, lack of trust, financial constraints, and limited participation of private enterprises, which were identified by SA. Therefore, a legal framework with specific regulations and guidelines is required. There also needs to be a mechanism to enable non-state stakeholders (private enterprises, local residents, farmers, CSOs, ACs, etc.) to take responsibility for operating the system and to benefit from their contributions.

Dynamic economic growth in Asia has been accompanied by a worrying rapid increase in the volume and complex changes in the composition of waste. The significant presence of organic waste in the waste stream has represented a constant challenge to all countries in the region. Subsequent research, therefore, should strive to determine the tendency of generated organic waste in terms of volume, density, moisture, and calorific value. In addition, it is also necessary to identify the similarities and differences among regional countries with regard to the technical, financial, institutional, legal, social, and economic aspects in order to propose a guiding framework for the formulation of sustainable strategic plans for organic waste management in the region.

This study focuses on composting and assumes it to be a suitable method of organic waste recycling in a largely agriculture-based economy, such as Vietnam. However, as organic waste has become a global issue, not only for developing, but also for developed countries, due to increased food waste $[4,10,33]$; relying only on recycling does not guarantee a sustainable solution to the problem. Composting is essentially a principle in the performance of circular economy. The circular economy, however, is more about preventing than recycling waste. It also attempts to switch from the present model of production and consumption (take, make, waste) that is discoloring soil and generating waste at an alarming rate to one that maximizes resource efficiency and minimizes the amount of natural resources required in production and waste discharged into the environment [31]. For this shift to take place, we will need the consensus and cooperation of all parties. Therefore, it is necessary in the current situation to examine factors influencing the awareness and cooperation of stakeholders in moving away from the old economic model to a circular one. Subsequent research can adopt a multilevel framework to assess the roles, responsibilities, and the interdependencies of stakeholders in the realization of a circular economy at the microlevel (producers' and consumers' responsibilities in food production, sale, and consumption), at the meso-level (reuse and recycle organic resources within eco-industrial parks), or at the macrolevel (circular economy development in cities, provinces, or regions (e.g., eco-city, collaborative consumption models, or zero-waste programs)).

This study demonstrates that SA and SNA are complementary and together can provide an effective method to assess and understand the overall system. This approach could be helpful for assessment at all stages of a project cycle. However, SA and SNA have their own shortcomings in the sense that they can only create maps of information on an ad hoc basis at one certain point in time. Therefore, the process of development and the changes in roles, awareness, and attitudes of stakeholders over time have not been captured [39]. Further research can redress this shortcoming by amassing information at two different evaluation points: past and present. However, this also further complicates the interview process, timing, and budgeting issues. In fact, being able to approach specialized agencies of the city is already a challenge per se.

Author Contributions: All the authors contributed in the research design, questionnaire construction, and interpretation of data analysis. N.P.L. and T.T.P.N. collected and analyzed the data and wrote the article. D.Z. refined and critically reviewed the article.

Funding: This research received no external funding. 
Acknowledgments: The authors would like to thank the Doctoral Scholarship Scheme of China Government and Tongji University, Shanghai, China for making this research possible.

Conflicts of Interest: The authors declare no conflict of interest.

\section{References}

1. Ministry of Natural Resource and Environment (MONRE). Vietnam National Report 2011-Solid Waste; Ministry of Natural Resource and Environment: Hanoi, Vietnam, 2011; (In Vietnamese). Available online: http:/ / vea.gov.vn/vn/hientrangmoitruong/baocaomtquocgia/ (accessed on 1 March 2018).

2. Hanoi People Committee (HPC). Planning for Treating Municipal Solid Waste of Hanoi to 2030 and to Vision 2050; Hanoi People Committee: Hanoi, Vietnam, 2014. (In Vietnamese)

3. Hoornweg, D.; Thomas, L.; Otten, L. Composting and Its Applicability in Developing Countries; The World Bank: Washington, DC, USA, 1999.

4. Asian Development Bank (ADB). Toward Sustainable Municipal Organic Waste Management in South Asia: A Guidebook for Policy Makers and Practitioners; Asian Development Bank: Manila, Philippines, 2011; p. 75. ISBN 9789290923954.

5. Zurbrügg, C.; Drescher, S.; Rytz, I.; Sinha, A.H.M.M.; Enayetullah, I. Decentralised composting in Bangladesh, a win-win situation for all stakeholders. Resour. Conserv. Recycl. 2005, 43, 281-292. [CrossRef]

6. Thanh, N.P.; Matsui, Y. Compost Potential from Solid Waste: Toward Sustainable Agriculture and Mitigation of Global Warming in the Mekong Delta, Vietnam. In Environmental Change and Agricultural Sustainability in the Mekong Delta; Springer: Dordrecht, The Netherlands, 2011; pp. 335-354.

7. Chen, Y.-T. A Cost analysis of food waste composting in taiwan. Sustainability 2016, 8, 1210. [CrossRef]

8. Wei, Y.; Li, J.; Shi, D.; Liu, G.; Zhao, Y.; Shimaoka, T. Environmental challenges impeding the composting of biodegradable municipal solid waste: A critical review. Resour. Conserv. Recycl. 2017, 122, 51-65. [CrossRef]

9. Oliveira, L.S.; Oliveira, D.S.; Bezerra, B.S.; Pereira, B.S.; Battistelle, R.A.G. Environmental analysis of organic waste treatment focusing on composting scenarios. J. Clean. Prod. 2017, 155, 229-237. [CrossRef]

10. Thi, N.B.D.; Kumar, G.; Lin, C.-Y. An overview of food waste management in developing countries: current status and future perspective. J. Environ. Manag. 2015, 157, 220-229. [CrossRef] [PubMed]

11. Heckman, J.R. Soil fertility management a century ago in farmers of forty centuries. Sustainability 2013, 5, 2796-2801. [CrossRef]

12. Hargreaves, J.; Adl, M.; Warman, P. A review of the use of composted municipal solid waste in agriculture. Agric. Ecosyst. Environ. 2008, 123, 1-14. [CrossRef]

13. Baud, I.; Post, J.; Furedy, C. Solid Waste Management and Recycling: Actors, Partnerships and Policies in Hyderabad, India and Nairobi, Kenya; Springer: Dordrecht, The Netherlands, 2006; Volume 76, ISBN 1402025297.

14. Caniato, M.; Vaccari, M.; Visvanathan, C.; Zurbrügg, C. Using social network and stakeholder analysis to help evaluate infectious waste management: A step towards a holistic assessment. Waste Manag. 2014, 34, 938-951. [CrossRef] [PubMed]

15. Van de Klundert, A.; Anschütz, J. Integrated Sustainable Waste Management_The Concept; WASTE: Gouda, The Netherlands, 2001; ISBN 9076639027.

16. Guerrero, L.A.; Maas, G.; Hogland, W. Solid waste management challenges for cities in developing countries. Waste Manag. 2013, 33, 220-232. [CrossRef] [PubMed]

17. Read, A.D. Making waste work: making UK national solid waste strategy work at the local scale. Resour. Conserv. Recycl. 1999, 26, 259-285. [CrossRef]

18. Barr, S.; Guilbert, S.; Metcalfe, A.; Riley, M.; Robinson, G.M.; Tudor, T.L. Beyond recycling: An integrated approach for understanding municipal waste management. Appl. Geogr. 2013, 39, 67-77. [CrossRef]

19. Chung, S.S.; Lo, C.W. Local waste management constraints and waste administrators in China. Waste Manag. 2008, 28, 272-281. [CrossRef] [PubMed]

20. Ali, A. Wasting time on solid waste in developing countries. Waste Manag. 2010, 30, 1437-1438. [CrossRef] [PubMed]

21. Troschinetz, A.M.; Mihelcic, J.R. Sustainable recycling of municipal solid waste in developing countries. Waste Manag. 2009, 29, 915-923. [CrossRef] [PubMed]

22. Hofmann, P. Wasted waste-Disappearing reuse at the peri-urban interface. Environ. Sci. Policy 2013, 31, 13-22. [CrossRef] 
23. Brown, K. Integrating conservation and development: A case of institutional misfit. Front. Ecol. Environ. 2003, 1, 479-487. [CrossRef]

24. Dietz, T.; Ostrom, E.; Stern, P.C. The struggle to govern the commons. Science 2003, 302, 1907-1912. [CrossRef] [PubMed]

25. Huppé, G.A.; Creech, H.; Knoblauch, D. The Frontiers of Networked Governance; International Institute for Sustainable Development: Winnipeg, MB, Canada, 2012.

26. Francesch-Huidobro, M. Climate change and energy policies in Shanghai: A multilevel governance perspective. Appl. Energy 2016, 164, 45-56. [CrossRef]

27. Lienert, J.; Schnetzer, F.; Ingold, K. Stakeholder analysis combined with social network analysis provides fine-grained insights into water infrastructure planning processes. J. Environ. Manag. 2013, 125, 134-148. [CrossRef] [PubMed]

28. Dos Muchangos, L.S.; Tokai, A.; Hanashima, A. Stakeholder analysis and social network analysis to evaluate the stakeholders of a MSWM system-A pilot study of Maputo City. Environ. Dev. 2017, 24, 124-135. [CrossRef]

29. Chen, W.-C.; Chen, W.-C.; Geng, D.-S. The strategy and bioenergy potential for kitchen waste recycling in Taiwan. J. Environ. Eng. Manag. 2008, 18, 281-287.

30. Ravetz, J. Integrated assessment for sustainability appraisal in cities and regions. Environ. Impact Assess. Rev. 2000, 20, 31-64. [CrossRef]

31. Ghisellini, P.; Cialani, C.; Ulgiati, S. A review on circular economy: the expected transition to a balanced interplay of environmental and economic systems. J. Clean. Prod. 2016, 114, 11-32. [CrossRef]

32. Reed, M.S.; Graves, A.; Dandy, N.; Posthumus, H.; Hubacek, K.; Morris, J.; Prell, C.; Quinn, C.H.; Stringer, L.C. Who's in and why? A typology of stakeholder analysis methods for natural resource management. J. Environ. Manag. 2009, 90, 1933-1949. [CrossRef] [PubMed]

33. Xu, W.; Zhou, C.; Cao, A.; Luo, M. Understanding the mechanism of food waste management by using stakeholder analysis and social network model: An industrial ecology perspective. Ecol. Modell. 2016, 337, 63-72. [CrossRef]

34. Grimble, R. Stakeholder Methodologies in Natural Resource Management; Natural Resources Institute: Gillingham, UK, 1998; ISBN 0859544966.

35. Crosby, B. Stakeholder Analysis: A Vital Tool for Strategic Managers; USAID's Implementing Policy Change Project: Washington, DC, USA, 1992.

36. Suškevičs, M.; Tillemann, K.; Külvik, M. Assessing the relevance of stakeholder analysis for national ecological network governance: The case of the Green Network in Estonia. J. Nat. Conserv. 2013, 21, 206-213. [CrossRef]

37. Snel, M.; Ali, M. Stakeholder Analysis in Local Solid Waste Management Schemes; Water and Environment Health at London and Loughborough: London, UK; Loughborough, UK, 1999.

38. Rheinländer, T.; Thanh Xuan, L.T.; Ngoc Hoat, L.; Dalsgaard, A.; Konradsen, F. Hygiene and sanitation promotion strategies among ethnic minority communities in Northern Vietnam: A stakeholder analysis. Health Policy Plan. 2012, 27, 600-612. [CrossRef] [PubMed]

39. Zurbrügg, C. Assessment Methods for Waste Management Decision-Support in Developing Countries. Ph.D. Thesis, Università Degli Studi di Brescia, Brescia, Italy, 2013.

40. Wasserman, S.; Faust, K. Social Network Analysis: Methods and Applications; Cambridge University Press: Cambridge, UK, 1994; Volume 8, ISBN 0521387078.

41. Ramalingam, B. Tools for Knowledge and Learning: A Guide for Development and Humanitarian Organizations; Overseas Development Institute: London, UK, 2006; ISBN 0850038138.

42. Borgatti, S.P.; Mehra, A.; Brass, D.J.; Labianca, G. Network analysis in the social sciences. Science 2009, 323, 892-895. [CrossRef] [PubMed]

43. Salpeteur, M.; Calvet-Mir, L.; Diaz-Reviriego, I.; Reyes-García, V. Networking the environment: Social network analysis in environmental management and local ecological knowledge studies. Ecol. Soc. 2017, 22, 41. [CrossRef]

44. Prell, C.; Hubacek, K.; Reed, M. Stakeholder analysis and social network analysis in natural resource management. Soc. Nat. Resour. 2009, 22, 501-518. [CrossRef]

45. Bodin, Ö.; Crona, B.I. The role of social networks in natural resource governance: What relational patterns make a difference? Glob. Environ. Chang. 2009, 19, 366-374. [CrossRef] 
46. Stein, C.; Ernstson, H.; Barron, J. A social network approach to analyzing water governance: The case of the Mkindo catchment, Tanzania. Phys. Chem. Earth Parts A/B/C 2011, 36, 1085-1092. [CrossRef]

47. Cohen, P.J.; Evans, L.S.; Mills, M. Social networks supporting governance of coastal ecosystems in Solomon Islands. Conserv. Lett. 2012, 5, 376-386. [CrossRef]

48. Hauck, J.; Schmidt, J.; Werner, A. Using social network analysis to identify key stakeholders in agricultural biodiversity governance and related land-use decisions at regional and local level. Ecol. Soc. 2016, 21, 49. [CrossRef]

49. Driscoll, D.L.; Appiah-Yeboah, A.; Salib, P.; Rupert, D.J. Merging qualitative and quantitative data in mixed methods research: How to and why not. Ecol. Environ. Anthropol. 2007, 3, 19-28.

50. Molina-Azorín, J.F.; López-Gamero, M.D. Mixed methods studies in environmental management research: prevalence, purposes and designs. Bus. Strateg. Environ. 2016, 25, 134-148. [CrossRef]

51. Crona, B.; Bodin, Ö. What you know is who you know? Communication patterns among resource users as a prerequisite for co-management. Ecol. Soc. 2006, 11, 7. [CrossRef]

52. Hanoi Statistical Office (HSO). Hanoi Statistical Yearbook 2015; Hanoi Statistical Office: Hanoi, Vietnam, 2016. (In Vietnamese)

53. Taniguchi, Y.; Yoshida, M. Public involvement and mobilization for promoting 3R initiative in Hanoi City: Lessons from 3R initiative project in Hanoi City 2006-2009. In Proceedings of the 8th Expert Meeting on Solid Waste Management in Asia and Pacific Islands (SWAPI), Tokyo, Japan, 21-23 February 2011; p. 23.

54. Anh, M.T.P.; Ali, M.; Anh, H.L.; Ha, T.T.T. Urban and Peri-Urban Agriculture in Hanoi: Opportunities and Constraints for Safe and Sustainable Food Production; AVRDC-The World Vegetable Center: Shanhua, Taiwan, 2004; Volume 32, ISBN 92-9058-137-9.

55. Bryson, J.M.; Patton, M.Q.; Bowman, R.A. Working with evaluation stakeholders: A rationale, step-wise approach and toolkit. Eval. Progr. Plan. 2011, 34, 1-12. [CrossRef] [PubMed]

56. Dougill, A.; Fraser, E.; Holden, J.; Hubacek, K.; Prell, C.; Reed, M.; Stagl, S.; Stringer, L. Learning from doing participatory rural research: lessons from the Peak District National Park. J. Agric. Econom. 2006, 57, 259-275. [CrossRef]

57. Eden, C.; Ackermann, F. Making Strategy: The Journey of Strategic Management; Sage: London, UK, 1998; ISBN 0761952241.

58. Freeman, R.E. Strategic Management: A Stakeholder Approach; Pitman Publishing: Boston, MA, USA, 1984; ISBN 0273019139.

59. Savage, G.T.; Nix, T.W.; Whitehead, C.J.; Blair, J.D. Strategies for assessing and managing organizational stakeholders. Executive 1991, 5, 61-75. [CrossRef]

60. Hanneman, R.A.; Riddle, M. Introduction to Social Network Methods; University of California Riverside: Riverside, CA, USA, 2005.

61. Freeman, L.C.; Roeder, D.; Mulholland, R.R. Centrality in social networks: II. Experimental results. Soc. Netw. 1979, 2, 119-141. [CrossRef]

62. Borgatti, S.P.; Everett, M.G.; Freeman, L.C. Ucinet for Windows: Software for social network analysis. Conections 1992, XV,1-2.

63. Nguyen, T.T.P.; Zhu, D.; Le, N.P. Factors influencing waste separation intention of residential households in a developing country: Evidence from Hanoi, Vietnam. Habitat Int. 2015, 48, 169-176. [CrossRef]

64. Nguyen, T.T.P. Utilizing Urban Solid Waste in Urban Agriculture: Willingness to Separate Waste, Willingness to Pay for Compost and Involvement of Stakeholders-A Case Study of Hanoi, Vietnam. Ph.D. Thesis, Tongji University, Shanghai, China, 2016.

65. Aleluia, J.; Ferrão, P. Characterization of urban waste management practices in developing Asian countries: A new analytical framework based on waste characteristics and urban dimension. Waste Manag. 2016, 58, 415-429. [CrossRef] [PubMed]

66. Yadav, P.; Samadder, S. A critical review of the life cycle assessment studies on solid waste management in Asian countries. J. Clean. Prod. 2018, 185, 492-515. [CrossRef]

67. Pandyaswargo, A.H.; Premakumara, D.G.J. Financial sustainability of modern composting: the economically optimal scale for municipal waste composting plant in developing Asia. Int. J. Recycl. Organ. Waste Agric. 2014, 3, 4. [CrossRef]

68. Pariatamby, A.; Fauziah, S. Sustainable 3R practice in the Asia and Pacific Regions: the challenges and issues. In Municipal Solid Waste Management in Asia and the Pacific Islands; Springer: Singapore, 2014; pp. 15-40. 
69. Houng, H.; Shen, S.-H.; Ma, H.-K. Municipal Solid Waste Management in Taiwan: From Solid Waste to Sustainable Material Management. In Municipal Solid Waste Management in Asia and the Pacific Islands; Springer: Singapore, 2014; pp. 317-336.

70. Manomaivibool, P. Municipal Solid Waste Management in Bangkok: The Cases of the Promotion of Source Reduction and Source Separation in Bangkok and in Roong Aroon School. Master's Theses, Lund University, Lund, Sweden, 2005.

71. Sharp, A.; Sang-Arun, J. A Guide for Sustainable Urban Organic Waste Management in Thailand: Combining Food, Energy and Climate Co-Benefits. 2012. Available online: https:/ /www.apn-gcr.org/resources/files / original/a38dd72155088c9924789b2aa10b780b.pdf (accessed on 3 July 2018).

72. Chen, Y.-T.; Chang, D.-S. Diffusion effect and learning effect: An examination on MSW recycling. J. Clean. Prod. 2010, 18, 496-503. [CrossRef]

73. Lu, L.-T.; Hsiao, T.-Y.; Shang, N.-C.; Yu, Y.-H.; Ma, H.-W. MSW management for waste minimization in Taiwan: The last two decades. Waste Manag. 2006, 26, 661-667. [CrossRef] [PubMed]

74. Um, M.H.; Lee, Y. Quality Control for Commercial Compost in Korea; ASPAC Food and Fertilizer Technology Center: Taipei, Taiwan, 2001.

75. Min, D.-K.; Rhee, S.-W. Management of Municipal Solid Waste in Korea. In Municipal Solid Waste Management in Asia and the Pacific Islands; Springer: Singapore, 2014; pp. 173-194.

76. Lee, S.; Paik, H.S. Korean household waste management and recycling behavior. Build. Environ. 2011, 46, 1159-1166. [CrossRef]

77. Sukholthaman, P.; Chanvarasuth, P.; Sharp, A. Analysis of waste generation variables and people's attitudes towards waste management system: A case of Bangkok, Thailand. J. Mater. Cycles Waste Manag. 2017, 19, 645-656. [CrossRef]

78. Siriratpiriya, O. Municipal solid waste management in Thailand: challenges and strategic solution. In Municipal Solid Waste Management in Asia and the Pacific Islands; Springer: Singapore, 2014; pp. 337-354.

79. Vassanadumrongdee, S.; Kittipongvises, S. Factors influencing source separation intention and willingness to pay for improving waste management in Bangkok, Thailand. Sustain. Environ. Res. 2018, 28, 90-99. [CrossRef]

80. Kirama, A.; Mayo, A.W. Challenges and prospects of private sector participation in solid waste management in Dar es Salaam City, Tanzania. Habitat Int. 2016, 53, 195-205. [CrossRef]

81. Scammell, M.K. Qualitative environmental health research: An analysis of the literature, 1991-2008. Environ. Health Perspect. 2010, 118, 1146-1154. [CrossRef] [PubMed]

82. Vartiainen, P. The substance of stakeholder evaluation: Methodological discussion. Int. J. Public Adm. 2003, 26, 1-18. [CrossRef]

83. Grimble, R.; Wellard, K. Stakeholder methodologies in natural resource management: A review of principles, contexts, experiences and opportunities. Agric. Syst. 1997, 55, 173-193. [CrossRef]

84. Kanbar, N.N. Analyzing Individual Behavior in Commons Dilemmas: A Study of Collective Action in Source Separation of Wastes. Ph.D. Thesis, George Mason University, Fairfax, VA, USA, 2005.

85. Yau, Y. Domestic waste recycling, collective action and economic incentive: The case in Hong Kong. Waste Manag. 2010, 30, 2440-2447. [CrossRef] [PubMed]

86. Loan, L.T.T. Analysis of Households' Behavior and Preference toward Sustainable Municipal Organic Waste Management in Hoi An, Vietnam. Ph.D. Thesis, Kyushu University, Fukuoka, Japan, 2017.

87. Price, J.C.; Leviston, Z. Predicting pro-environmental agricultural practices: The social, psychological and contextual influences on land management. J. Rural Stud. 2014, 34, 65-78. [CrossRef]

88. Ouédraogo, E.; Mando, A.; Zombré, N. Use of compost to improve soil properties and crop productivity under low input agricultural system in West Africa. Agric. Ecosyst. Environ. 2001, 84, 259-266. [CrossRef]

(C) 2018 by the authors. Licensee MDPI, Basel, Switzerland. This article is an open access article distributed under the terms and conditions of the Creative Commons Attribution (CC BY) license (http://creativecommons.org/licenses/by/4.0/). 